INEEL/EXT-99-00574

FECEIVED

NOV 082000

OSTI

\title{
Workshop for Conducting Phase 2 of the INTEC Glass Composition Variation Study
}

\author{
B. A. Staples \\ C. A. Musick \\ Published June 1999 \\ Idaho National Engineering and Environmental Laboratory \\ High-Level Waste Program \\ Lockheed Martin Idaho Technologies Company \\ Idaho Falls, Idaho 83415
}

\author{
Prepared for the \\ U.S. Department of Energy \\ Assistant Secretary for Environmental Management \\ Under DOE Idaho Operations Office \\ Contract DE-AC07-94ID13223
}




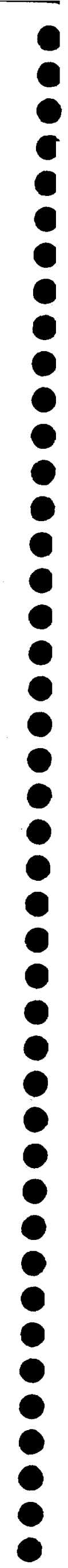




\section{DISCLAIMER}

This report was prepared as an account of work sponsored by an agency of the United States Government. Neither the United States Government nor any agency thereof, nor any of their employees, make any warranty, express or implied, or assumes any legal liability or responsibility for the accuracy, completeness, or usefulness of any information, apparatus, product, or process disclosed, or represents that its use would not infringe privately owned rights. Reference herein to any specific commercial product, process, or service by trade name, trademark, manufacturer, or otherwise does not necessarily constitute or imply its endorsement, recommendation, or favoring by the United States Government or any agency thereof. The views and opinions of authors expressed herein do not necessarily state or reflect those of the United States Government or any agency thereof. 


\section{DISCLAIMER}

Portions of this document may be illegible in electronic image products. Images are produced from the best available original document. 


\section{ABSTRACT}

During March 30-31, 1999, the Phase 2 Idaho Nuclear Technology and Engineering Center (INTEC) Glass Composition Variation Study Workshop was held at the Shilo Inn in Idaho Falls, Idaho. The workshop had the purpose of establishing a preparation and characterization protocol for the phase $2 \mathrm{~b}$ glasses of the INTEC composition variation study. The workshop also had the purpose of reviewing the most recent estimates of INTEC high-level waste compositions for their impacts on the vitrification of these wastes. Waste composition estimates discussed included those of the various calcine types and of the high activity waste fractions from the calcine dissolution/separations process. Persons from the Idaho National Engineering and Environmental Laboratory (INEEL), Pacific Northwest National Laboratories (PNNL), and Savannah River Technology Center (SRTC) participated in this workshop. As a result of the workshop, details for the preparation and characterization of the phase $2 \mathrm{~b}$ matrix of glasses were completed. The impacts on vitrification of updated waste composition estimates were discussed. Actions for the preparation and characterization of the glasses and development of the separations flowsheet were established. 
0
0
0
0
0
0
0
0
0
0
0
0
0
0
0
0
0
0
0
0
0
0
0
0
0
0
0
0
0
0
0 


\section{SUMMARY}

The Phase 2 INTEC CVS workshop was held March 30 and 31, 1999 at the Shilo Inn in Idaho Falls, Idaho. This workshop provided a forum for collaborators from the INEEL, PNNL and SRTC to define the path forward in preparing and characterizing CVS phase $2 \mathrm{~b}$ glasses and to:

1. Review technical progress in TTP ID-77-WT31,

2. Present the background for the phase $2 \mathrm{~b}$ glass matrix,

3. Present the phase $2 b$ matrix, and

4. To address other items given in the Organization and Agenda section.

The workshop agenda is given on page xvii. A list of workshop attendees is given on page $x i x$.

Subjects addressed in the workshop include:

1. Updated estimates of calcine compositions in calcine storage bin sets 1-6,

2. Presentation and discussion of phase $2 \mathrm{a}$ test results,

3. Models for linking phase $1 \mathrm{~b}$ and phase $2 \mathrm{~b}$ composition-property relationships,

4. Phase $2 \mathrm{~b}$ test matrix discussion,

5. Review of laboratory procedures to be used at INEEL, PNNL, SRTC for preparing and characterizing the phase $2 \mathrm{~b}$ glasses,

6. Review of full separations flowsheet and compositions,

7. Review and discussion of options for pretreatment/separations flowsheet and the resulting HAW fraction compositions, and

8. Separations process path forward and review.

As a result of addressing these subjects, several actions and conclusions came from this workshop.

The calcine composition estimates updated at the workshop (See Appendix A) will be known as "March 1999 estimates." These were used to derive phase $2 a$ and $2 b$ glasses. The phase $2 a$ glasses (See Appendix B) were prepared to observe the effects on product characteristics of higher concentrations of calcium and fluorine as given in the March 1999 estimates of calcine compositions. These effects were used to determine limits for each component in phase $2 \mathrm{~b}$ composition space and for deriving property models used to link phase $1 \mathrm{~b}$ and phase $2 \mathrm{~b}$ glasses (See Appendix $\mathrm{C}$ ). Only the properties of homogeneous phase $1 \mathrm{~b}$ glasses were used to define these models. The derivation 
of the phase $2 b$ matrix of glasses (See Appendix D), its nature and the selection of compositions from it for preparation and characterization were discussed at the workshop.

A major purpose of the workshop was to establish the preparation and characterization protocols for the phase $2 \mathrm{~b}$ glasses. Preparation and characterization would be performed in INTEC laboratories with support from PNNL and SRTC personnel. Agreement was established on the conduct of procedures for preparation, composition analysis, electronic analysis, durability testing, canister centerline cooling $(C C C)$ tests, liquidus temperature $\left(T_{L}\right)$ detemination, and viscosity determination. Details of these procedures are given in this document (See pages 2-3). The report that captures the results of preparing and characterizing glasses of the phase $2 \mathrm{~b}$ CVS test matrix will be issued by LMITCO personnel assigned to TTP ID-77-WT31.

Current full separations flowsheets and their HAW compositions (See Appendices E and F) were discussed. The major changes in the current HAW composition estimates, when compared to earlier versions, is reduction of the phosphate amount used in the separations process. Because of phosphate reduction in HAWs, the effects of other elements on vitrification must be considered. These elements currently include aluminum, calcium, fluorine, molybdenum, potassium, sulfur and zirconium. With the characterization of undissolved solids (UDS), more elements may be identified as having impacts on the vitrification process. Alteration of the separations flowsheet for the purpose of controlling the amounts of these elements was discussed. Personnel from PNNL and SRTC will issue a document that summarizes the impact on the vitrification process and glass product properties by elements present at high concentrations in HAWs. The content of this document will provide guidance during separations process development in optimizing HAW compositions for vitrification. 


\section{ACKNOWLEDGMENTS}

The authors acknowledge the guidance and resources provided for this multi-institutional task from the U.S. Department of Energy's (USDOE) Tanks Focus Area. The following persons made significant technical contributions toward the completion of this workshop.

\begin{tabular}{l} 
INEEL \\
\hline Charles Barnes \\
John Harbour \\
Scott Herbst \\
James Herzog \\
Jack Law \\
Arlin Olson \\
James Rindfleisch \\
Brad Scholes \\
Terry Todd \\
Don Wood
\end{tabular}

PNNL

Pavel Hrma

Greg Piepel

John Vienna

SRTC

Tommy Edwards

Bill Holtzscheiter

Carol Jantzen

David Peeler

The following persons made significant contributions toward issuing this report.

Sharla Mickelsen, INEEL Ina Moore, INEEL

Funding to conduct this workshop, a milestone of Technical Task Plan(TTP) ID-77WT-31, Subtask B was provided by the USDOE Office of Science and Technology. 


\section{CONTENTS}

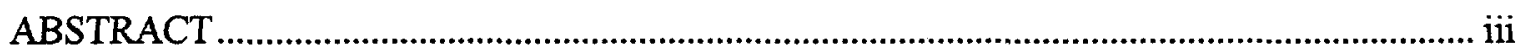

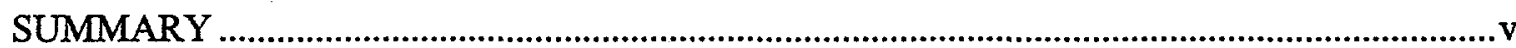

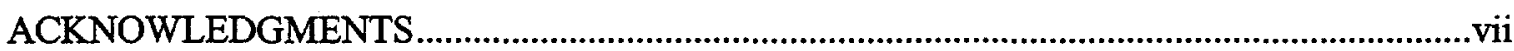

ACRONYMS

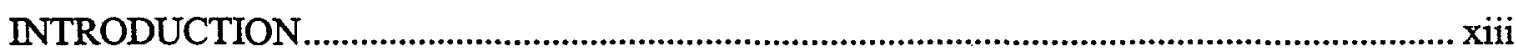

BACKGROUND

ORGANIZATION AND AGENDA ........................................................................................

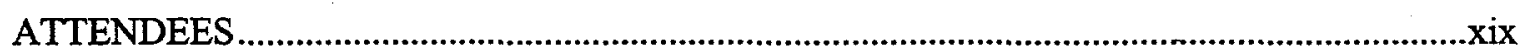

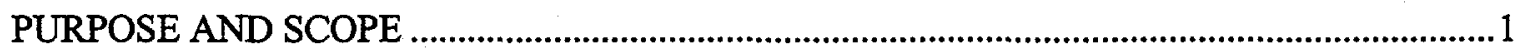

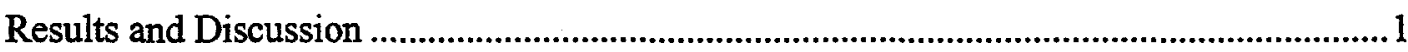

Updated Estimates of Calcine Compositions in Bin Sets 1-6 ..................................

Presentation and Discussion of Phase 2a Test Results ............................................... 1

Models for linking Phase 1 and Phase $2 \mathrm{~b}$ Composition-Property Relationship............ 1

Discussion on Selecting Phase $2 \mathrm{~b}$ Test Matrix …........................................................2

Review and Discussion of Laboratory Procedures

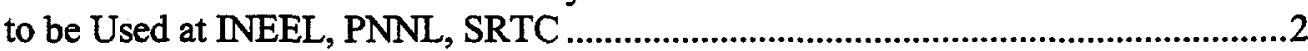

Review of Responsibilities for Issuing Final Report on Phase $2 b$ Test Matrix............4

Review of Full Separations Flowsheets and Compositions........................................4

Review and Discussion of Options for Pretreatment/Separations

Flowsheet and Their Resulting HAW Fraction Compositions.....................................4

Path Forward for Vitrification-Separations Interface ..................................................4

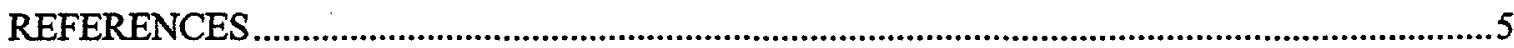

Appendix A-Current Estimates of Calcine Compositions in Bin Sets 1-6

Appendix B-Review of CVS Phase 2a Test Results

Appendix C-Review of CVS Phase 1 Data and Preliminary CVS Phase 2 Models

Appendix D-Review of Phase $2 b$ CVS Test Matrix

Appendix E-Review of full Separations Flowsheet and Compositions

Appendix F-Review of Options for Pretreatment/Separations Flowsheet and their Resulting HAW Fraction Compositions 

$:$
$:$
$:$ 


\section{ACRONYMS}

\begin{tabular}{|c|c|}
\hline $\mathrm{CCC}$ & Canister centerline cooling \\
\hline CVS & Composition variation study \\
\hline DOE & Department of Energy \\
\hline DWPF & Defense Waste Processing Facility \\
\hline EGCR & Experimental glass composition range \\
\hline HAW & High activity waste fraction \\
\hline INEEL & Idaho National Engineering and Environmental Laboratory \\
\hline INTEC & Idaho Nuclear Technology and Engineering Center \\
\hline LMITCO & Lockheed Martin Idaho Technologies Company \\
\hline NBS & National Bureau of Standards \\
\hline PCT & Product consistency test \\
\hline PNNL & Pacific Northwest National Laboratory \\
\hline SBW & Sodium bearing waste \\
\hline SEM & Scanning electron microscopy \\
\hline SRTC & Savannah River Technology Center \\
\hline $\mathrm{T}_{\mathrm{L}}$ & Liquidus temperature \\
\hline TTP & Technical task plan \\
\hline UDS & Undissolved solids \\
\hline $\mathrm{XRD}$ & $\mathrm{X}$-ray diffraction analysis \\
\hline
\end{tabular}




\section{INTRODUCTION}

Two significant options exist for the vitrification of calcined high-level waste (HLW) being stored at the INEEL's Idaho Nuclear Technology and Engineering Center (INTEC).

Separations-The "Separations" option dissolves retrieved calcine, then separates the radionuclides into a fraction of reduced mass. This fraction is known as the high activity waste fraction (HAW). Because of its significantly reduced mass compared to calcine, the "Separations" option has the potential for resulting in a much smaller mass of vitrified product that will go to a federal repository for storage. The separations process isolates and separates the radionuclides but also retains a significant amount of aluminum and zirconium from the dissolved calcine. The separations process also adds phosphate and potassium to the HAW. The concentrations of these elements in the HAW place its composition outside those of expected wastes to be immobilized in the DOE complex.

Direct Vitrification-The "Direct Vitrification" option vitrifies calcine as it is retrieved from the storage bins. The direct vitrification process appears simpler than the separations process, however a significantly larger mass of vitrified product results from it. The calcines have unique and complex compositions. Zirconia calcine, which comprises about $80 \%$ of the HLW mass stored at INTEC, contains high concentrations of calcium, zirconium and fluorine. Alumina calcine, the other major calcined waste, consists of as much as $90 \%$ alumina by mass. The concentrations in calcines of the elements discussed above are outside those expected in wastes to be immobilized in the DOE complex.

Because of the uniqueness of calcined HLW and the separated HAW compositions, a cooperative composition variation study (CVS) is in progress at the INEEL, PNNL and SRTC. This study has the goal of defining the composition-product characteristics of glasses being developed to vitrify the INTEC wastes. Performing the CVS is a subtask of Technical Task Plan (TTP) ID-77-WT31. As currently defined, the multi-year scope of this CVS is designed to be performed in two or more phases. The first phase began in FY98. This phase has been completed and its results described. ${ }^{1}$ The second phase of the CVS began in FY99. Other phases may follow, depending on the results of phase $2 \mathrm{~b}$ and the quality of INTEC waste composition estimates. Glasses to be prepared and characterized during phase $2 \mathrm{~b}$ have been composed using updated estimates of the HAW and calcined waste compositions.

Given the range of the HAW and calcined HLW composition estimates, mixture design techniques were applied at PNNL to derive a glass formulation matrix for the first phase of the CVS. ${ }^{2}$ Formulations for preparation and characterization with respect to homogeneity, viscosity, liquidus temperature and leaching response to the PCT were derived from this matrix through systematic selection. This approach is being applied to the derivation of phase $2 b$ glass formulations. Phase $2 a$ was performed to provide information that would link the results of phase $1 \mathrm{~b}$ glass characteristics and the new estimates of INTEC wastes to phase $2 \mathrm{~b}$. However, because of the interest in direct vitrification, the availability of updated estimates of calcine composition and the results of phase 1 , a forum was required to establish final details in the approach to conducting phase $2 \mathrm{~b}$ of the CVS. 


\section{BACKGROUND}

During FY-98, technical progress was made in TTP D-77-WT31. This progress is a necessary precursor for performing additional phases of the CVS. The most significant progress made in phase 1 of the CVS includes:

1. Establishment of the ability to determine the liquidus temperature $\left(\mathrm{T}_{\mathrm{L}}\right)$ on molten glass at INTEC laboratories,

2. Computerization of viscosity determinations on molten glass to obtain more reproducible results,

3. Application of the composition variation study (CVS) approach to the definition of an experimental glass composition region for INTEC waste compositions,

4. Observation of the approximate limit of phosphate concentration in the borosilicate phase 1 CVS glasses,

5. Observation of $\mathrm{T}_{\mathrm{L}}$ in CVS glasses containing phosphate and of the principal phase $\left(\mathrm{Li}_{3} \mathrm{PO}_{4}\right)$ crystallizing at this temperature,

6. Observation of $T_{L}$ in the absence of phosphate in the CVS glasses and of the principal phase $\left(\mathrm{Li}_{2} \mathrm{SiO}_{3}\right)$ crystallizing at this temperature,

7. Completion of CVS glass viscosity profiles as a function of melt temperature, and

8. Observation of effect of cooling apparently homogeneous CVS glasses at the rate expected at the centerline of a full-scale DWPF canister.

In addition, updated estimates of high activity waste (HAW) fraction compositions were available because of progress in FY98 in developing the separations flowsheets. Likewise, resources were available in FY98 to obtain more detailed estimates of INTEC calcined waste compositions. 


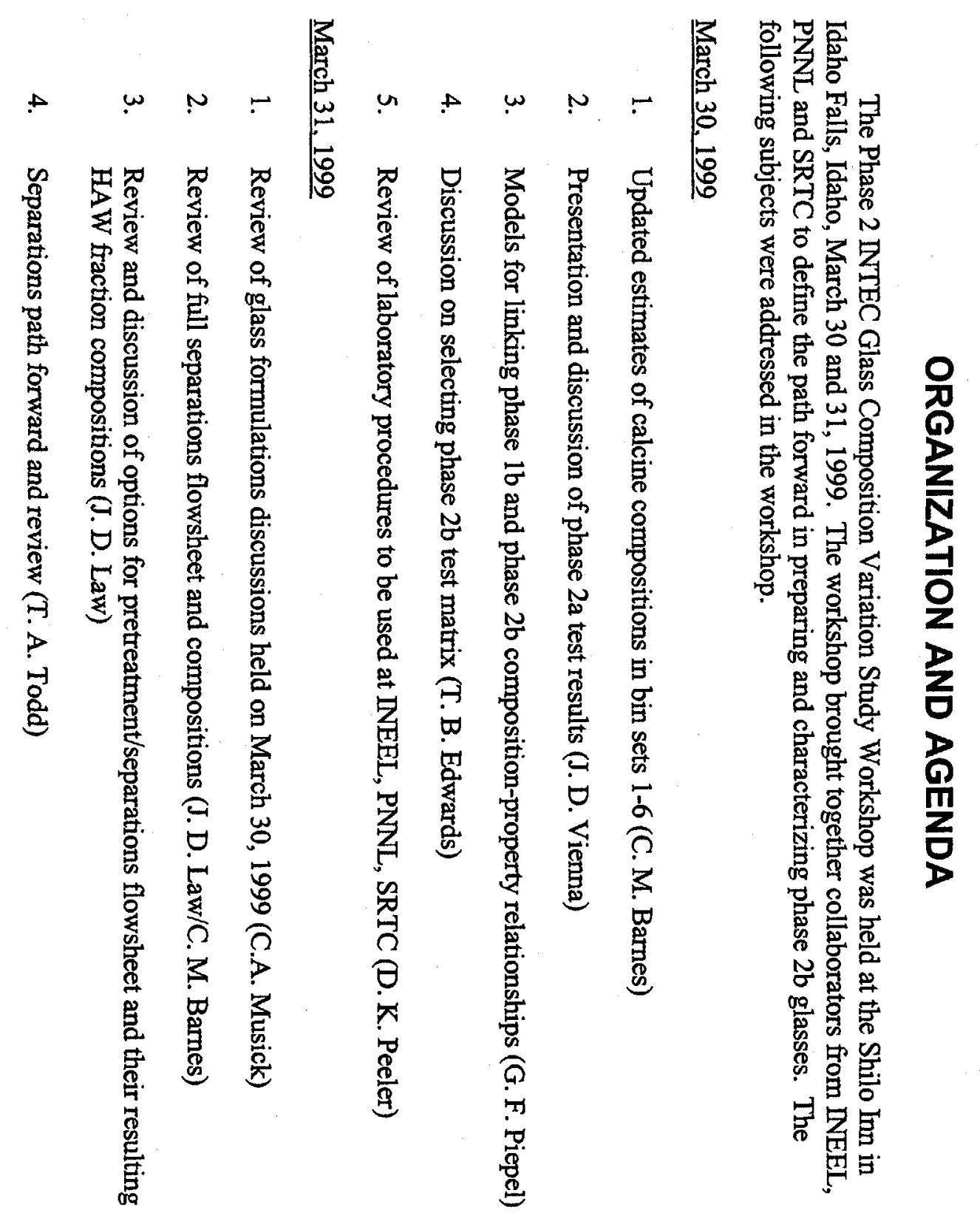




\section{ATTENDEES}

Pacific Northwest National Laboratory

Greg Piepel

John Vienna

$\underline{\text { Savannah River Technology Center }}$

Tommy Edwards

John Harbour

David Peeler
Idaho National Engineering

Environmental Laboratory

Charles Barnes

Arlin Olson

Dan Griffith

Jim Rindfleisch

Scott Herbst

Bruce Staples

Jack Law

Terry Todd

Chris Musick

Don Wood 
0000000000000000000000000000000000000000000 


\title{
Workshop for Conducting Phase 2 of the INTEC Glass Composition Variation Study
}

\section{PURPOSE AND SCOPE}

\author{
Conducting this workshop and the issue of this report satisfy Milestone A2-2 of the FY99 \\ Technical Task Plan (TTP) ID-77-WT31. The development activities and goals of Section A of this TTP \\ allow for the performance of phase $2 b$ of the CVS. \\ This workshop provided a forum to: \\ 1. Review the technical progress in the task, \\ 2. Present the background for the phase $2 b$ glass matrix, \\ 3. Present the phase $2 \mathrm{~b}$ matrix, \\ 4. Build the mechanism by which the glasses in the matrix would be prepared and \\ characterized, and \\ 5. To address other items given in the Organization and Agenda section.
}

\section{Results and Discussion}

As a result of the discussions held on the subjects given in the workshop agenda, conclusions and recommendations were made. These follow with respect to each agenda item as given above.

\section{Updated Estimates of Calcine Compositions in Bin Sets 1-6}

Information presented is the same as that released earlier in 1999. The only change is that material presented in the workshop includes nitrate and carbonate content estimates. These were omitted from information released earlier this year. The information presented here will be known as the "March 1999 calcine composition estimates."

\section{Presentation and Discussion of Phase 2a Test Results}

Calcium and fluoride concentrations are major differences between the phase $2 \mathrm{~b}$ and phase $1 \mathrm{~b}$ matrices. Fluoride was not a component in phase $1 \mathrm{~b}$, and calcium concentrations were much less in phase $1 b$ than in phase $2 b$. Phase $2 a$ was performed to observe the effects of higher and varying concentrations of these two components on glass solubility/volatilization, durability and viscosity. These observations from phase 2 a provided the upper and lower limits for each of these components in phase $2 \mathrm{~b}: \mathrm{CaO} ; 0.0-12$ mass \%, and $\mathrm{F}: 0.0-6.0$ mass \%. These components would be varied independently of each other in the phase $2 b$ test matrix, and property coefficients obtained from the phase $2 \mathrm{a}$ studies would be used to define the phase $2 \mathrm{~b}$ compositional space.

\section{Models for linking Phase 1 and Phase 2b Composition-Property Relationship}

Only the eighteen homogeneous phase $1 \mathrm{~b}$ glasses were used to provide PCT durability $(\mathrm{B}, \mathrm{Li}, \mathrm{Na})$ and viscosity data for the composition-property models used to link phase $1 \mathrm{~b}$ and phase $2 \mathrm{~b}$ glasses. These models underpredict this relationship and suggest that the worst boron releases are within the range of 
inhomogeneous glasses. The model used to link viscosity of phase $1 \mathrm{~b}$ and phase $2 \mathrm{~b}$ glasses also underpredicts relationship with composition. Both these first order models, however, appear to be suitable for use in defining the phase $2 b$ matrix.

\section{Discussion on Selecting Phase 2b Test Matrix}

Mixture analysis techniques were applied for defining the phase $2 \mathrm{~b}$ matrix, and the limits of the twelve major components were based on the March 1999 composition estimates of calcine in the fourth bin set. Each major component is a dimension in the phase $2 \mathrm{~b}$ matrix. Minor components were combined in the dimension known as "Others." Limits of $\mathrm{Al}_{2} \mathrm{O}_{3}$ and $\mathrm{ZrO}_{2}$ and alkali metal oxides were set to screen out amounts that could result in potentially poor performers. The final experimental glass composition region (EGCR) contained over 16000 compositions summed across inner and outer layers. Glasses selected from the EGCR for preparation and characterization are fourteen from each layer including extreme vertices from each layer as well as duplicate pseudo-center points. Also added to the matrix are two homogeneous compositions (IG1-07 and IG1-38) from the phase $1 \mathrm{~b}$ matrix and a "boss point" which is a pseudo center without "Others." This subset chosen for preparation and characterization appears to adequately address the range of waste compositions and was therefore converted to target batching compositions.

\section{Review and Discussion of Laboratory Procedures to be Used at INEEL, PNNL, SRTC}

Formal presentations were not made in the discussion of laboratory procedures to be used for the preparation and characterization of phase $2 b$ glasses. This aspect of the workshop was conducted in a "round table" manner without prepared visual aids. Glass would be prepared and characterized in the manner presented below. Preparation would be performed at INTEC laboratories. Characterization would also be performed in NTEC laboratories with support in specific areas, as discussed below, provided by personnel at PNNL and SRTC laboratories.

Glass Preparation. Batching of each glass of the phase $2 \mathrm{~b}$ matrix will be in accordance with the matrix to be supplied to INTEC personnel by T. B. Edwards before the end of April, 1999. Batches of mixed reactants for each formulation will be ground to pass a 100 mesh sieve then vitrified in $250-\mathrm{ml}$ $90 \% \mathrm{Pt} / 10 \% \mathrm{Rh}$ high form crucibles. A mass of mixed reactants that will fill each crucible to its limit will constitute a batch. Each batch will be brought up to the vitrification temperature of $1150^{\circ} \mathrm{C}$ and held there for an hour. On completion of this time period, the glass formed will be poured onto a quench plate, cooled to ambient temperature, ground to pass a 100 mesh sieve, and remelted for an hour at the same temperature. Any glass, such as that remaining in crucibles after pouring, containing visual residues after this treatment will be ground and remelted. Higher temperatures will be applied, if necessary, to achieve a visually homogeneous product. On achieving this condition, characterization testing will begin.

\section{Characterization Testing}

Glass Composition Analysis - Centroid glass, IG2-33 will be prepared first. This will be performed at INTEC and characterization with respect to composition will be completed at SRTC and INTEC before other phase $2 b$ glasses are prepared. This action will be performed to ensure that a target product composition can be achieved. Of particular interest in the composition analysis will be the retention of fluoride in the glass. This analysis is necessary to determine whether or not more fluoride must be added in order to attain the target amount in the IG2-33 formulation product. Fluoride determination will be performed at the INTEC and SRTC laboratories. SRTC personnel also will send a sample of IG2-33 glass to the Corning analytical laboratories for independent fluoride analysis. 
Electronic Analysis-X-ray diffraction analysis (XRD) will be performed on all phase $2 b$ glasses. This analysis will be performed at INTEC's analytical laboratories. Scanning electron microscopy (SEM) will be performed on all glasses in which phase separation can be observed through optical microscopy, but not through XRD. SEM analyses will be performed at INTEC analytical laboratories.. On request from INTEC personnel, transmission electron microscopy (TEM) will be applied at SRTC to glasses in which glass in glass separation cannot be detected by visual or optical means.

Durability - The durability of phase $2 \mathrm{~b}$ glasses will be observed by subjecting them to ASTM-C-1285-94, the Product Consistency Test (PCT). This action will include standardization and cleaning as described in ASTM C-1285-94. Reagent blanks and standards (ARM and EA) will be processed with the leach tests and the resulting leachates analyzed. Glasses will be processed in duplicate in the ratio of 1.5 grams of sample to $15 \mathrm{ml}$ of deionized, distilled water. Portions of IG2-33 prepared for PCT testing will also be submitted to SRTC for PCT testing to compare with results obtained in INTEC laboratories. Personnel from SRTC recommend that customized analytical standards should be prepared after the composition of IG2-33 is determined. The analysis is needed in order to base the composition of this standard. Aliquots of this standard should be processed with the glasses and analyzed with their leachates. High Purity Chemists, Inc. has experience in making up these types of standards.

Glass composition analyses must be completed in order to normalize elemental leachabilities. These analyses can be performed according to SRTC mobile laboratory procedures. If INTEC analytical laboratories have no fluoride procedure that can be performed on dissolved glass, then the mobile laboratory can perform this analysis. If INTEC analytical laboratories cannot provide timely services, the SRTC mobile analytical laboratory can perform all PCT leachate analyses. In this case, it would be best to submit all leachates to the laboratory at the same time.

Canister Centerline Cooling Tests-Canister centerline cooling (CCC) tests will be performed in $90 \% \mathrm{Pt} / 10 \% \mathrm{Rh}$ high form crucibles. A portion of the quenched glasses prepared as described above will be used for testing. The cooling rate applied from the vitrification temperature of $1150^{\circ} \mathrm{C}$ will be the same as used for the phase $1 \mathrm{~b}$ glasses. ${ }^{3}$ Samples of the glasses formed under these cooling conditions will be subjected to electronic analysis as described above. An amount will also be archived for being subjected to the PCT in the future.

Liquidus Temperature-Liquidus temperature $\left(T_{L}\right)$ will be performed at INTEC in the same manner as on phase $1 \mathrm{~b}$ glasses at PNNL. In this case, the gradient furnace was used to form glasses at temperature increments beginning at $1150^{\circ} \mathrm{C}$ and going down to where crystallization is first observed. For the purposes of this study, obtaining an estimate within $10^{\circ} \mathrm{C}$ of the true $\mathrm{T}_{\mathrm{L}}$ will be suitable. Before any phase $2 \mathrm{~b}$ samples are analyzed, NBS standard 773 glass should be run in the gradient furnace to observe how closely its $T_{L}$ can be approached. If necessary, samples can be prepared in the uniform temperature furnace to approach the standard's $T_{L}$ more closely. A sample of IG2-33, prepared as described above, will be sent to PNNL for confirmatory $T_{L}$ determination before $T_{L}$ is measured on other glasses.

Viscosity_-Viscosity profiles with respect to temperature will be performed at INTEC laboratories on phase $2 \mathrm{~b}$ glasses. These will be completed over the temperature range of $950^{\circ} \mathrm{C}$ to $1250^{\circ} \mathrm{C}$ on each glass in the same manner as performed on phase $1 \mathrm{~b}$ glasses. Calibrating the viscometer's sample thermocouple is crucial before determining the viscosity of samples. National Bureau of Standards (NBS) glass 711 is preferred for calibration actions, but this glass is currently unavailable. It is recommended that NBS glass $710 \mathrm{~B}$ should be used in its place for calibration. Viscosity measurements at lower temperatures of the profile can be helpful in estimating where to expect crystallinity to begin forming during $T_{\mathrm{L}}$ measurements. During these measurements the effect of glass fluoride content on viscosity will be of particular interest. 


\section{Review of Responsibilities for Issuing Final Report on Phase 2b Test Matrix}

The report that captures the results of preparing and characterizing glasses of the phase $2 \mathrm{~b}$ CVS test matrix will be issued by LMTTCO personnel assigned to TTP ID-77-WT31. Preparation and characterization activities on these glasses may be performed at all three participating laboratories. All technical data and information intended to be included in this report must be completed and sent to LMITCO personnel before August 31, 1999.

\section{Review of Full Separations Flowsheets and Compositions}

Current HAW compositions were presented and discussed. The amount of phosphate coming from the separations process into the HAW from all calcine types must be reduced to result in compositions that will vitrify into homogeneous products. This necessity is based on the results of characterizing the phase $1 \mathrm{~b}$ glasses and is the basis for investigating options that reduce phosphate content. Other major components present in HAWs that may be cause for concern in vitrification after the reduction of phosphate include aluminum, calcium, fluorine as fluoride, potassium, molybdenum and zirconium. In the case of sodium bearing waste (SBW) HAW, relatively high amounts of sulfate must also be of concern in the vitrification process. Better estimates of undissolved solids (UDS) compositions are required not only for completing the composition of HAW and calcined $\mathrm{HLW}$ for vitrification, but also for completing the dissolution and separations processes.

\section{Review and Discussion of Options for Pretreatment/Separations Flowsheet and Their Resulting HAW Fraction Compositions}

Alterations in the separations flowsheet to effect phosphate reduction have been investigated through calculations. The impact of these calculations on the separations flowsheets for SBW, alumina calcine and zirconia calcine HAWs were presented and discussed. These calculations indicate that phosphate coming from strip solutions can be reduced in the processing of all three types of HAW. Large uncertainties remain in the composition and amount of UDS in calcines and SBW. The addition of UDS may have a significant impact on the amount of phosphate in HAWs, but in making the calculations to achieve phosphate reduction, only estimates are available of the UDS amounts and compositions. With reduction of phosphate in alumina calcine HAW, molybdenum and aluminum become the largest components present when UDS is included. With reduction of phosphate in zirconia calcine HAW, calcium and fluoride become the largest components present when UDS is included. In the case of SBW HAW, however, the addition of undissolved solids (UDS) increases the amount of phosphate in the waste. Potassium, sodium and sulfate remain the major components in SBW HAW in which UDS are included.

\section{Path Forward for Vitrification-Separations Interface}

In a "round table" discussion, separations personnel requested a guidance document that would relate the effects of major components of the various HAWs and calcined HLWs on the vitrification process and on CVS glass characteristics. This request was required because of the experience with $\mathrm{P}_{2} \mathrm{O}_{5}$ in phase $1 \mathrm{~b}$ glasses and because $\mathrm{P}_{2} \mathrm{O}_{5}$ has been a major species in the separations flowsheet. With the reduction of $\mathrm{P}_{2} \mathrm{O}_{5}$ to concentrations that would have negligible effects on the properties of CVS glasses, other components could come into concentration levels that would be detrimental to those properties. Personnel from PNNL and SRTC therefore will issue a document that summarizes the impact of high concentrations of HAW and calcined HLW components on glass properties. 


\section{REFERENCES}

1. B. A. Staples, et. al, "The Preparation and Characterization of INTEC HAW Phase 1 Composition Variation Study Glasses," INEEL/EXT-98-00970, Rev. 1, March, 1999.

2. G. F. Piepel, J. D. Vienna and P. Hrma, "Phase 1 Experimental Design for the INEEL HLW Glass Composition Variation Study," PNNL-SA-29594, Rev. 2, January, 1999.

3. S. L. Marra and C. M. Jantzen, "Characterization of Projected DWPF Glasses Heat Treated to Simulate Canister Centerline Cooling (U)," WSRC-TR-92-142, Rev. 1, June, 1993 


\section{Appendix A \\ Current Estimates of Calcine Compositions in Bin Sets 1-6}


| 


\section{Calcine Bin Set Average Composition}

\begin{tabular}{|c|c|c|c|c|c|c|c|}
\hline & \multicolumn{2}{|c|}{ Bin Set 1 Bin Set 2} & \multicolumn{2}{|c|}{ Bin Set 3 Bin Set 4} & \multicolumn{2}{|c|}{ Bin Set 5 Bin Set 6} & \multirow{2}{*}{$\begin{array}{l}\text { Total } \\
\mathrm{Wt} \%\end{array}$} \\
\hline & $W t \%$ & $\mathrm{Wt} \%$ & $W_{t} \%$ & Wt $\%$ & $W_{t} \%$ & $\mathrm{Wt} \%$ & \\
\hline A & 83.05 & 33.44 & 13.65 & 11.92 & 13.26 & 41.26 & 21.78 \\
\hline B & 0.43 & 0.76 & 1.00 & 1.10 & 1.07 & 0.73 & 0.94 \\
\hline $\mathrm{Ca}$ & 0.00 & 23.25 & 30.79 & 34.45 & 29.65 & 12.65 & 26.80 \\
\hline Cd & 0.00 & 0.00 & 0.00 & 0.00 & 3.54 & 1.31 & 1.11 \\
\hline $\mathrm{CO} 3$ & 0.00 & 3.32 & 3.79 & 1.59 & 2.67 & 4.40 & 3.08 \\
\hline $\mathrm{Cr}$ & 0.00 & 0.19 & 0.25 & 0.30 & 0.15 & 0.22 & 0.21 \\
\hline $\mathbf{F}$ & 0.00 & 20.23 & 25.15 & 24.30 & 19.62 & 5.93 & 19.90 \\
\hline $\mathrm{Fe}$ & 1.47 & 0.16 & 0.28 & 0.65 & 0.63 & 1.05 & 0.51 \\
\hline $\mathrm{Hg}$ & 3.28 & 0.02 & 0.00 & 0.00 & 0.00 & 0.01 & 0.09 \\
\hline $\mathbf{K}$ & 0.00 & 0.17 & 0.24 & 0.53 & 0.80 & 2.00 & 0.60 \\
\hline $\mathrm{Mg}$ & 0.00 & 0.67 & 0.78 & 0.32 & 0.55 & 0.89 & 0.6 \\
\hline $\mathrm{Na}$ & 2.30 & 0.81 & 1.19 & 216 & 3.99 & 7.61 & 2.73 \\
\hline $\mathrm{NO} 3$ & 4.09 & 1.64 & 2.38 & 4.42 & 7.97 & 15.70 & 5.50 \\
\hline $\mathrm{PO4}$ & 1.87 & 0.41 & 1.18 & 0.09 & 0.22 & 0.43 & 0.57 \\
\hline Sr & 0.04 & 0.25 & 0.32 & 0.36 & 0.32 & 0.11 & 0.2 \\
\hline so & 2.81 & 0.64 & 0.61 & 0.14 & 2.43 & 1.75 & 1.23 \\
\hline$z r$ & 0.00 & 13.64 & 17.83 & 17.02 & 12.32 & 3.28 & 13.41 \\
\hline Total & 99.34 & 99.61 & 99.44 & 99.36 & 99.19 & 99.32 & 99.38 \\
\hline
\end{tabular}

\section{Calcine Bin Set Average Composition}

\begin{tabular}{|c|c|c|c|c|c|c|c|}
\hline & Bin Set 1 & in Set 2 & 3 in set 3 & $\operatorname{Bin}$ Set 4 & $\operatorname{Bin} \operatorname{Set} 5$ & Bin Set 6 & Total \\
\hline & popm & popm & $\mathrm{ppm}$ & ppm & ppm & ppm & ppm \\
\hline $\mathbf{B a}$ & 65 & 10 & 11 & 14 & 13 & 9 & 13 \\
\hline $\mathrm{Ce}$ & 71 & 11 & 13 & 16 & 15 & 10 & 15 \\
\hline Cl & 0 & 0 & 47 & 122 & 165 & 225 & 98 \\
\hline Cs & 71 & 22 & 15 & 18 & 19 & 13 & 19 \\
\hline La & 36 & 5 & 6 & 7 & 7 & 5 & 7 \\
\hline Mn & 0 & 0 & 32 & 0 & 25 & 76 & 24 \\
\hline Mo & 96 & 14 & 8 & 6 & 13 & 7 & 12 \\
\hline $\mathrm{Nb}$ & 0 & 0 & 8 & 13 & 241 & 6 & 71 \\
\hline Nd & 120 & 18 & 21 & 25 & 25 & 17 & 24 \\
\hline $\mathbf{N i}$ & 0 & 53 & 72 & 100 & 33 & 90 & 62 \\
\hline $\mathbf{P d}$ & 8 & 1 & 2 & 2 & 2 & 1 & 2 \\
\hline $\mathrm{Pr}$ & 33 & 5 & 6 & 7 & 7 & 5 & 7 \\
\hline$R h$ & 13 & 2 & 2 & 2 & 2 & 2 & 2 \\
\hline Ru & 47 & 7 & 4 & 3 & 6 & 7 & 6 \\
\hline $\mathrm{Sm}$ & 24 & 4 & 3 & 3 & 3 & 3 & 3 \\
\hline $\mathrm{sn}$ & 1 & 220 & 285 & 271 & 191 & 52 & 213 \\
\hline TC & 24 & 4 & 4 & 5 & 5 & 3 & 5 \\
\hline $\mathbf{u}$ & 16 & 2 & 10 & 11 & 15 & 131 & 23 \\
\hline Total & 625 & 378 & 548 & 624 & 787 & 662 & 605 \\
\hline
\end{tabular}




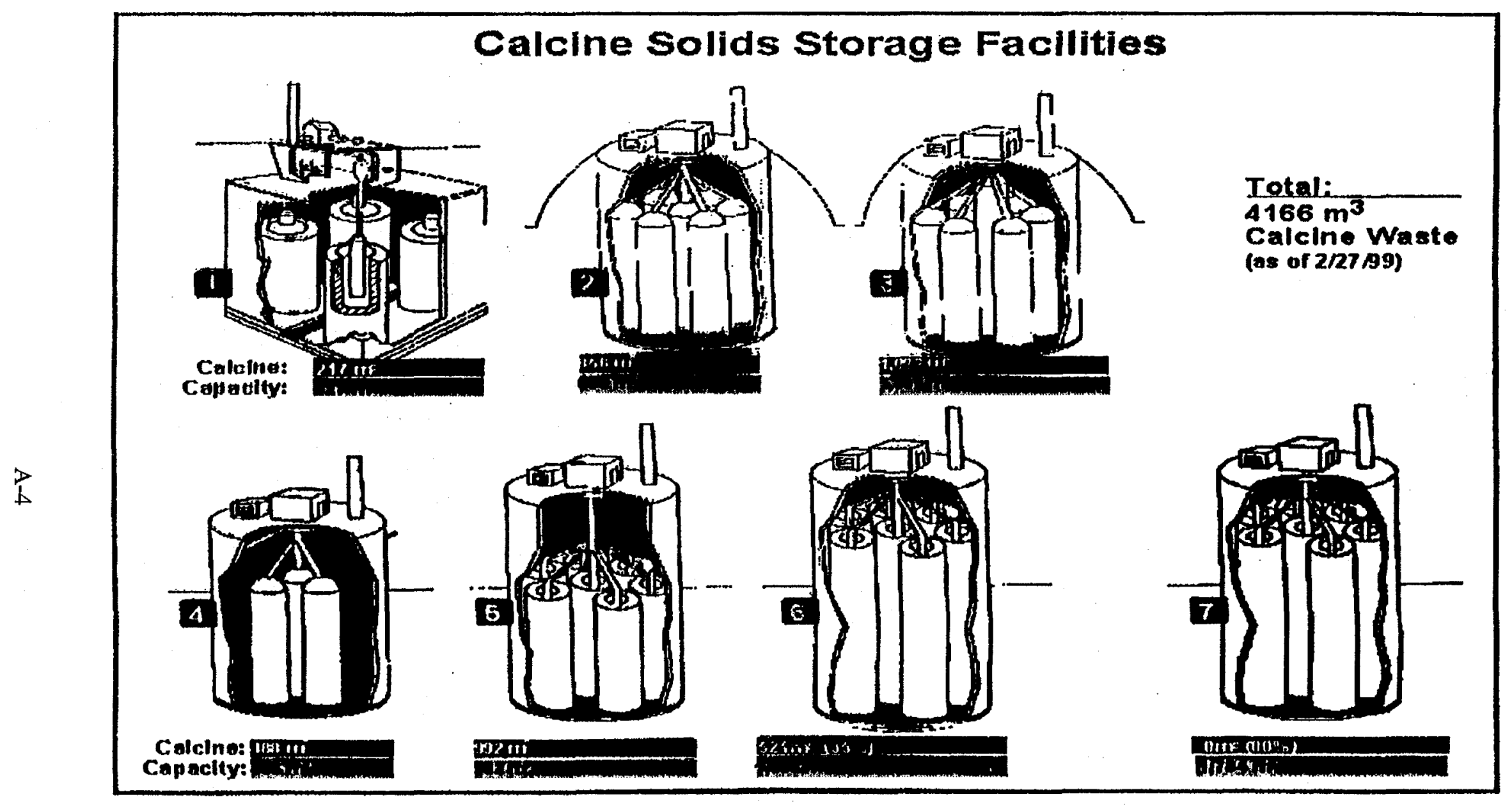

Cacline Solids Storage Facilities 




Calcine Stratification in Bin Set \#2 (ICPP-A-5257) 


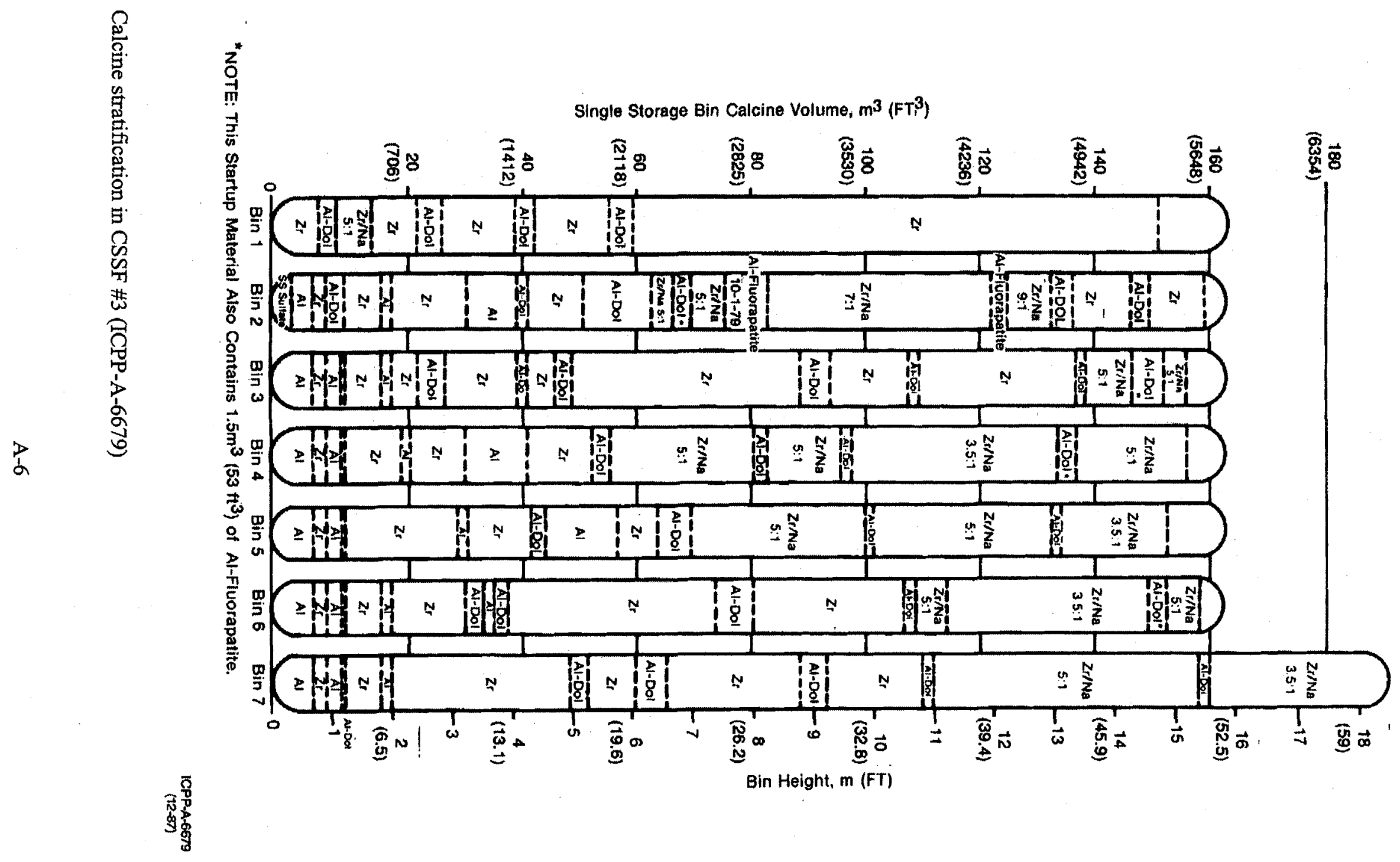






Calcine stratification in Bin Set \#4 (ICPP-A-10450) 


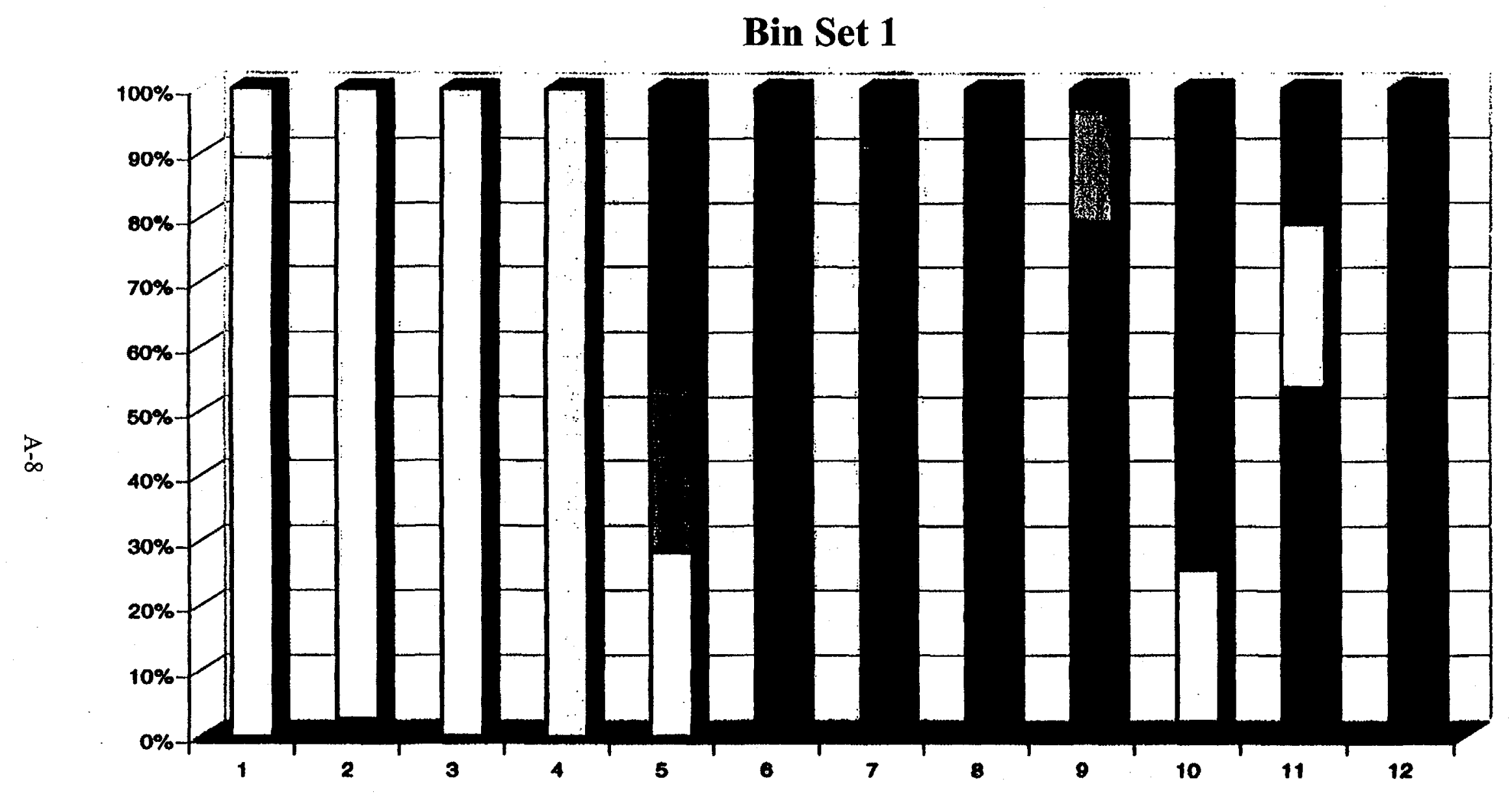

Bin Compartment 


\section{0}

\section{Bin 7 of Bin Set 2}

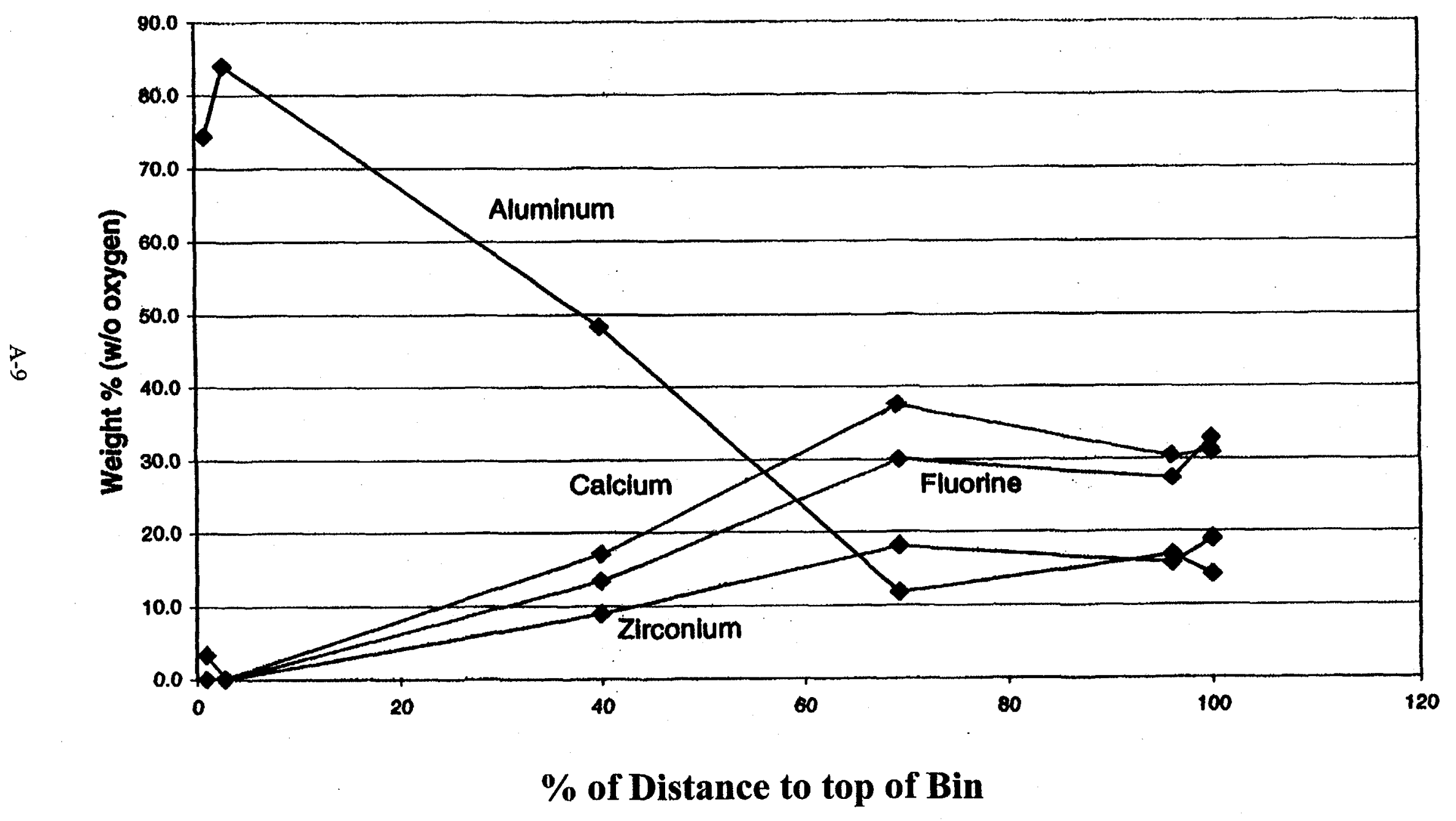


Bin 3 of Bin Set 3

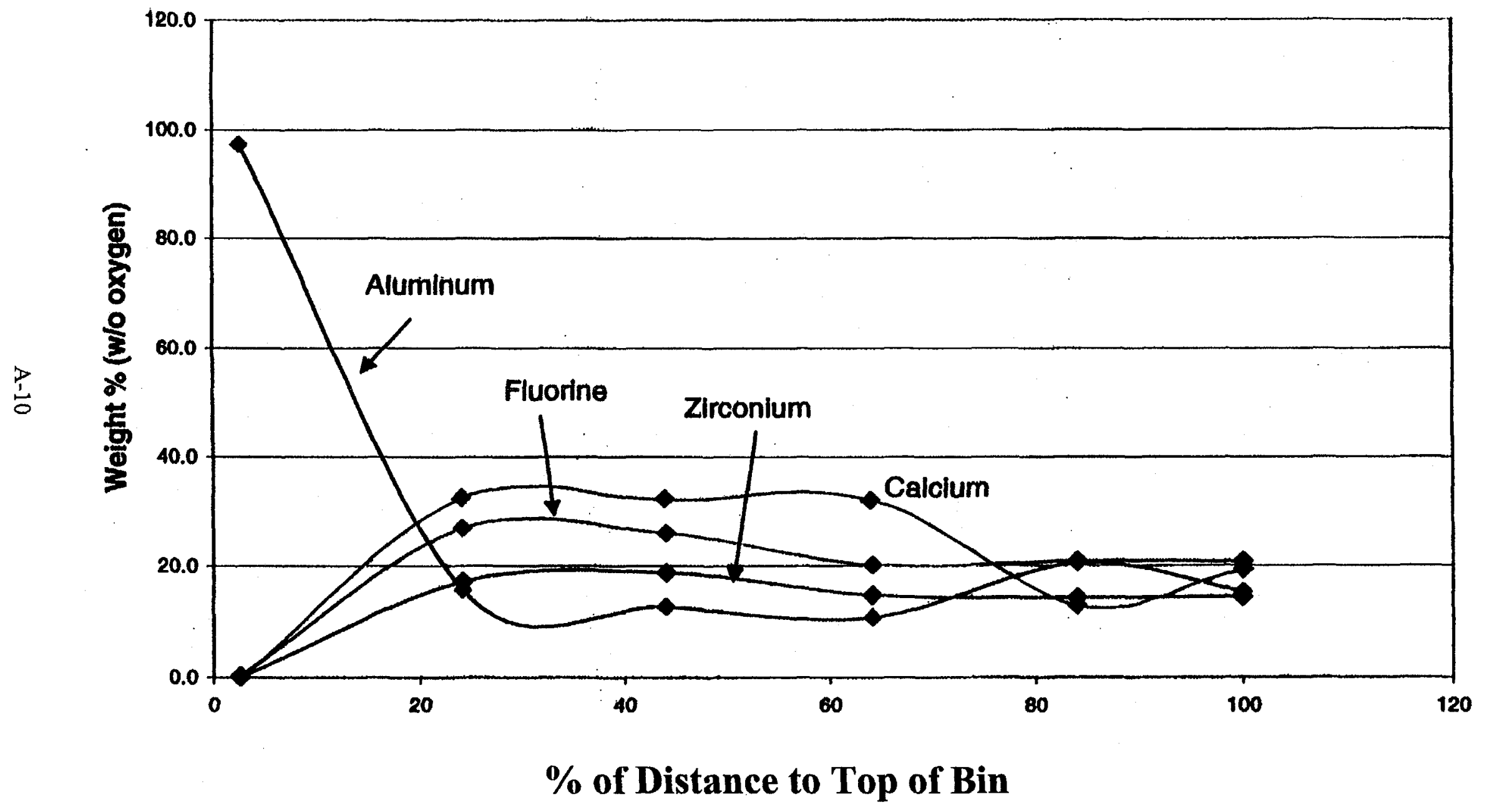




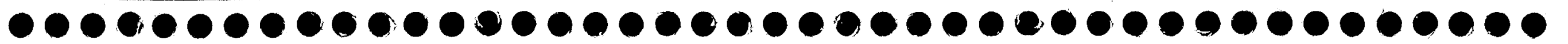

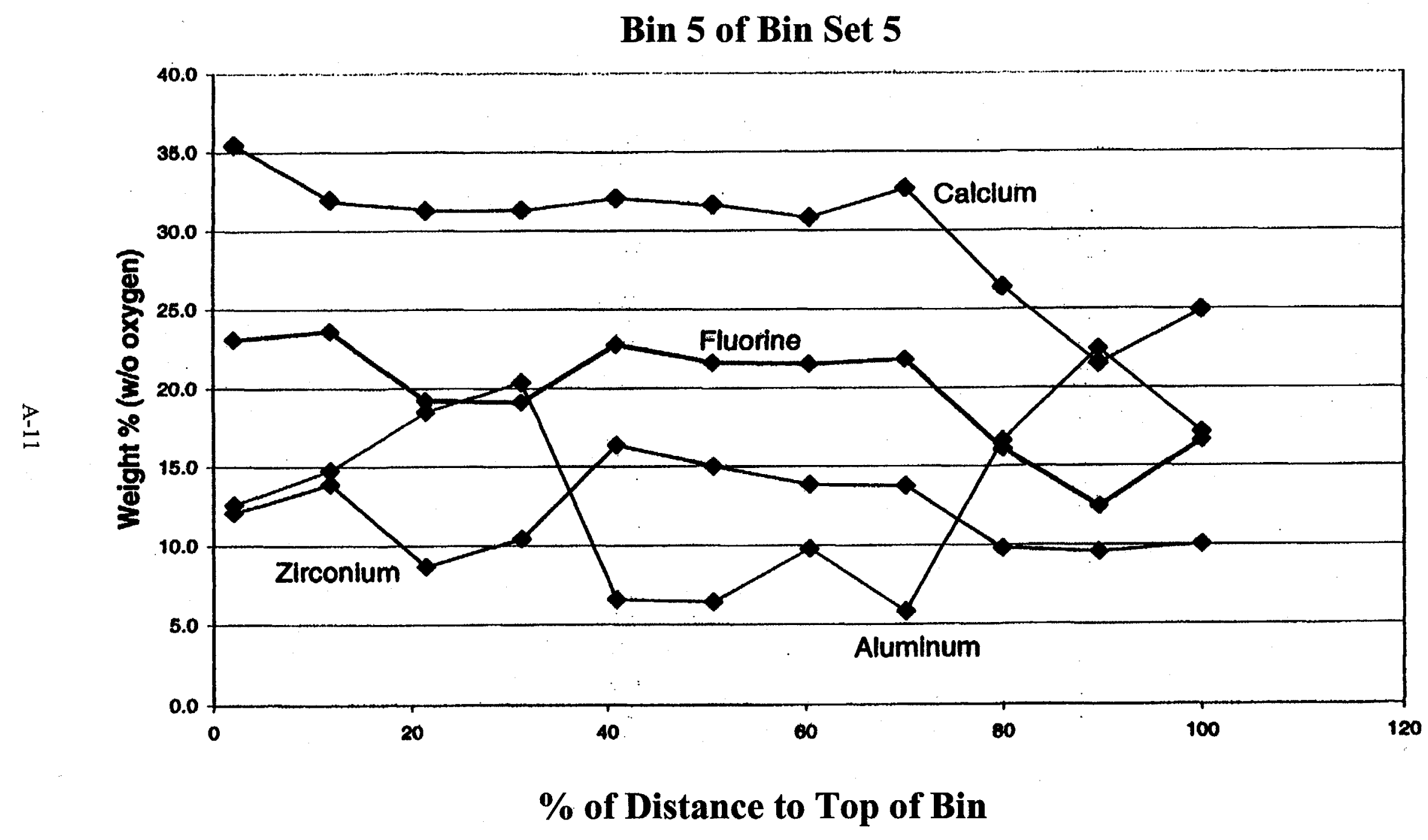




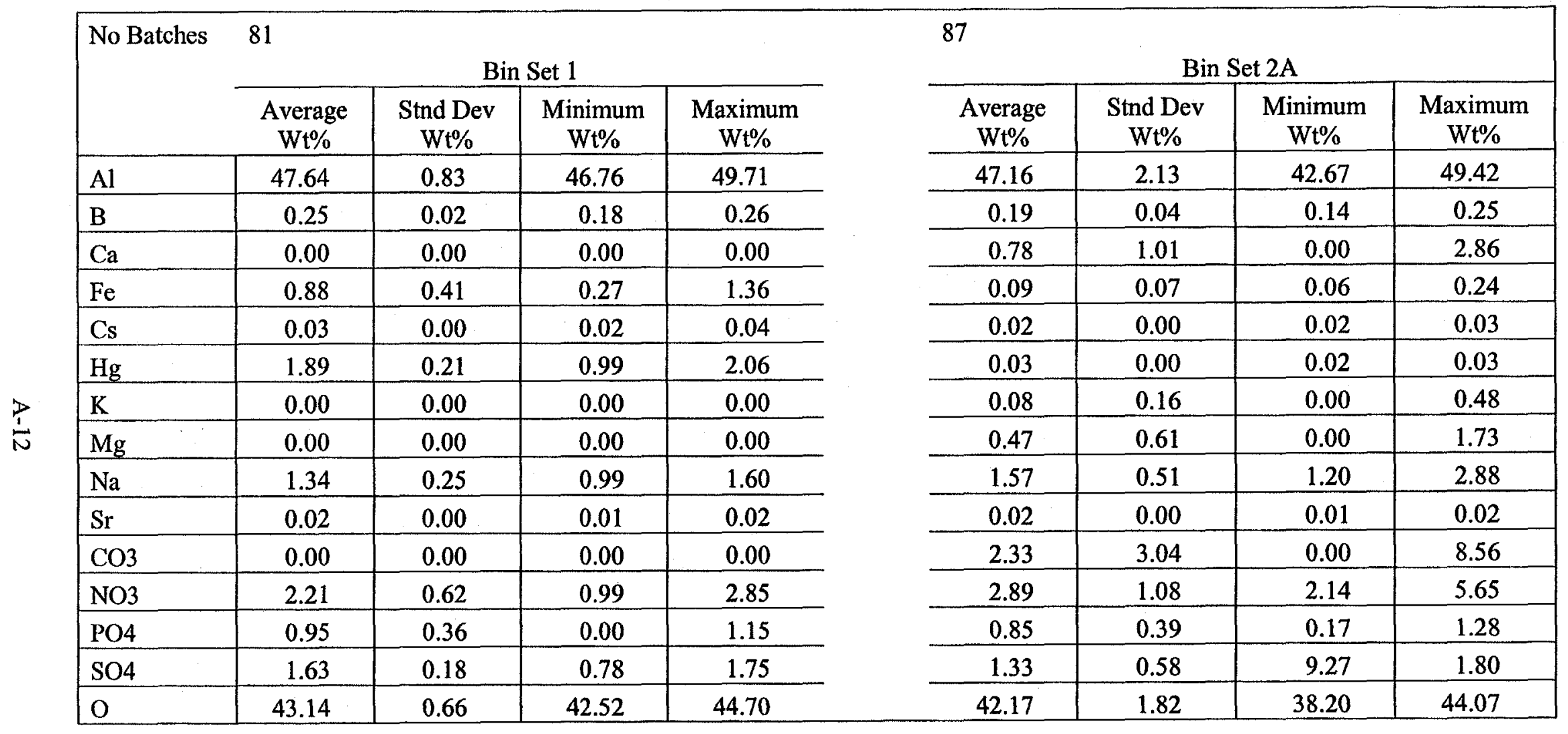




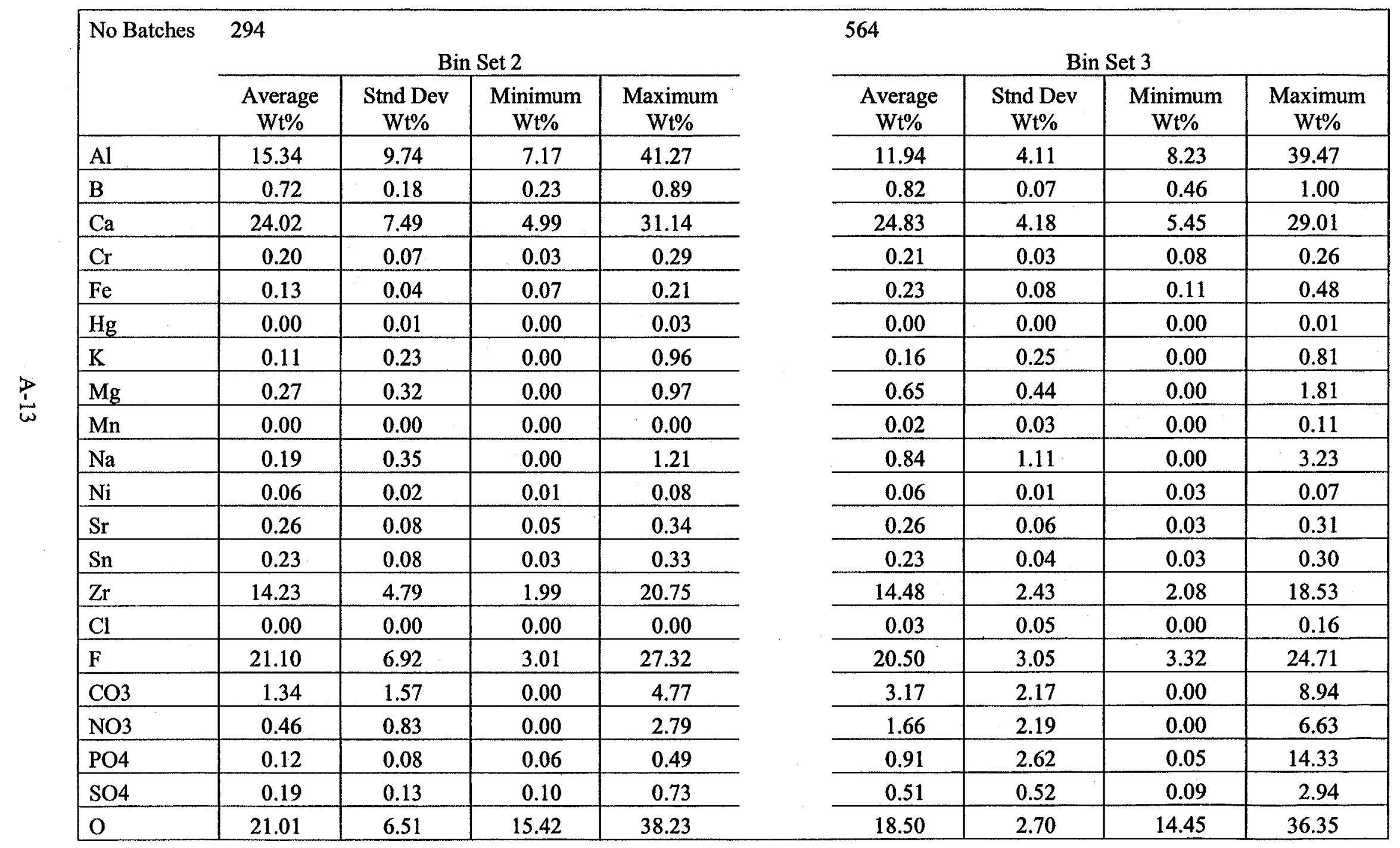




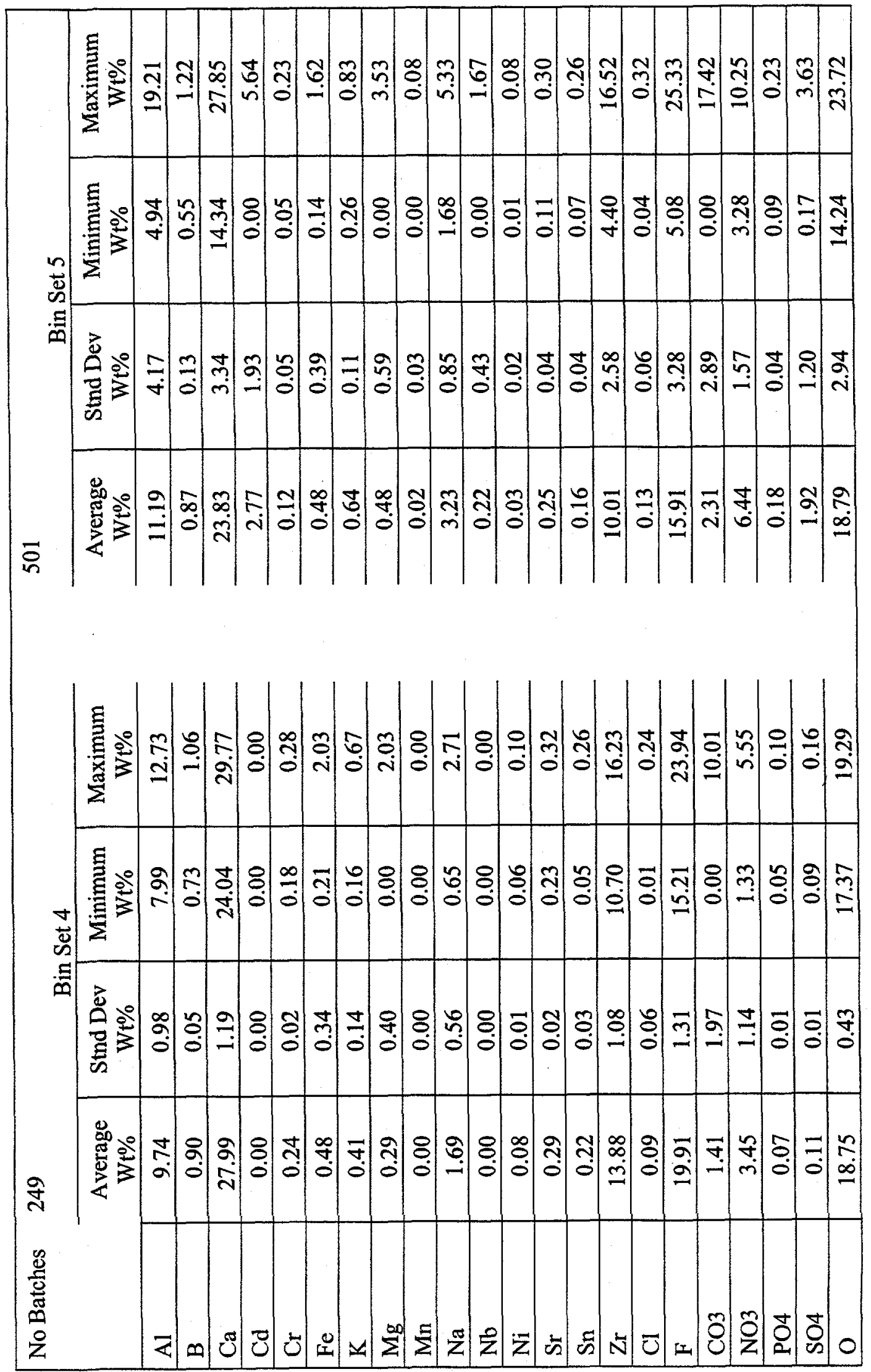




\begin{tabular}{|c|c|c|c|c|}
\hline \multirow[t]{2}{*}{ No. Batches } & \multicolumn{4}{|c|}{ Bin Set 6} \\
\hline & $\begin{array}{c}\text { Average } \\
\mathrm{Wt} \%\end{array}$ & $\begin{array}{c}\text { Stnd Dev } \\
W \mathrm{t} \%\end{array}$ & $\underset{W t \%}{\text { Minimum }}$ & $\underset{\mathrm{Wt} \%}{\text { Maximum }}$ \\
\hline $\mathrm{Al}$ & 27.80 & 5.62 & 18.96 & 34.09 \\
\hline B & 0.53 & 0.09 & 0.43 & 0.74 \\
\hline $\mathrm{Ca}$ & 9.77 & 4.29 & 4.44 & 16.23 \\
\hline $\mathrm{Cd}$ & 1.04 & 0.63 & 0.29 & 2.02 \\
\hline $\mathrm{Cr}$ & 0.15 & 0.06 & 0.05 & 0.23 \\
\hline $\mathrm{Fe}$ & 0.76 & 0.22 & 0.33 & 1.06 \\
\hline $\mathrm{K}$ & 1.33 & 0.57 & 0.53 & 1.99 \\
\hline $\mathrm{Mg}$ & 0.69 & 0.65 & 0.00 & 2.27 \\
\hline $\mathrm{Mn}$ & 0.04 & 0.03 & 0.00 & 0.08 \\
\hline $\mathrm{Na}$ & 5.17 & 0.90 & 3.08 & 6.60 \\
\hline $\mathrm{Ni}$ & 0.06 & 0.04 & 0.01 & 0.11 \\
\hline $\mathrm{Sr}$ & 0.03 & 0.04 & 0.00 & 0.12 \\
\hline $\mathrm{Sn}$ & 0.04 & 0.03 & 0.01 & 0.11 \\
\hline $\mathrm{U}$ & 0.03 & 0.01 & 0.01 & 0.04 \\
\hline $\mathrm{Zr}$ & 2.75 & 2.04 & 0.62 & 6.76 \\
\hline $\mathrm{Cl}$ & 0.15 & 0.04 & 0.09 & 0.21 \\
\hline $\mathrm{F}$ & 4.73 & 2.58 & 1.62 & 8.86 \\
\hline $\mathrm{CO} 3$ & 3.42 & 3.19 & 0.00 & 11.19 \\
\hline $\mathrm{NO} 3$ & 10.62 & 2.13 & 6.13 & 13.78 \\
\hline PO4 & 0.26 & 0.93 & 0.01 & 7.19 \\
\hline $\mathrm{SO} 4$ & 1.31 & 0.27 & 1.03 & 1.96 \\
\hline $\mathrm{O}$ & 29.31 & 4.07 & 23.08 & 33.98 \\
\hline
\end{tabular}




\section{Appendix B \\ Review of CVS Phase 2a Test Results}




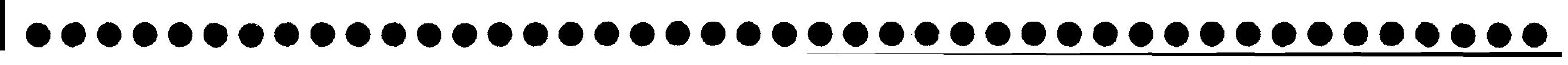




\section{PHASE 2A \\ SCOPING STUDIES}

J.D. Vienna, D.K. Peeler,

H. Li, and I.A. Reamer

Tanks Focus Area

March 30, 1999

OBJECTIVES

- Evaluate effects of $\mathrm{CaO}$ and $\mathrm{F}$ on primary processing and product performance properties

- solubility/volatilization, durability, viscosity

- Provide $\mathrm{CaO}$ and $\mathrm{F}$ bounds on which Phase $2 b$ "direct vitrification" test matrix would be established

- to minimize fabrication of unacceptable glasses 


\section{EXPERIMENTAL}

- Three Phase 2a baseline glasses fabricated

- CaO contents of $0.0,3.0$, and 10.0 mass \%

- target $F$ contents of $0.0,1.0,2.0,3.0,4.0$, and 5.0 mass $\%$ "spiked" at each $\mathrm{CaO}$ concentration

- $\mathrm{Na}_{2} \mathrm{O}_{\mathrm{Al}} \mathrm{O}_{3}$ ratio "fixed" at 2.24

- Melted at $1150^{\circ} \mathrm{C}$ for 4 hours (unless otherwise noted)

- Homogeneity evaluated via optical microscopy and/or XRD

- quenched and heat treated glasses

- Viscosity (rotating spindle technique)

- Durability (PCT-A, in duplicate) 


\section{PHASE 2a DATA}

\begin{tabular}{|c|c|c|c|c|c|c|c|c|c|c|c|c|c|c|}
\hline Glass ID & $\mathrm{CaO}$ & $F$ target & $F$ meas & size (g) & melt $T$ (C & nelt t th & $Q$ cryst. & HT cryst & visc (Pa.s) & PCT-B $(g / L)$ & PCT-Si $(g / L)]$ & PCT-Na $(g / L)$ & PCT-Li $(g / L)$ & $\mathrm{pH}$ \\
\hline $\mathrm{P2}-\mathrm{OCa}-\mathrm{OF}$ & 0.00 & 0.00 & - & 400 & 1150 & 4 & none & - & 14.90 & -- & - & - & - & $\cdots$ \\
\hline P2-0Ca-1F & 0.00 & 0.91 & 0.95 & 400 & 1150 & 4 & none & - & 11.30 & 0.53 & 0.25 & 0.62 & 0.44 & 10.09 \\
\hline$P 2-0 C a-3 F$ & 0.00 & 3.20 & -- & 300 & 1150 & $2 s$ & none & .- & - & -- & $\cdots$ & -- & - & - \\
\hline P2-0Ca-5F & 0.00 & 5.22 & - & 300 & 1150 & $2 \mathrm{~s}$ & $\mathrm{LiF}$ & - & - & + & - & $=$ & - & $\cdots$ \\
\hline P2-3C-aF & 3.00 & 0.00 & -- & 400 & 1150 & 4 & none & -- & 11.10 & - & - & - & $\cdots$ & -- \\
\hline P2-3Ca-1F & 2.69 & 0.91 & 0.89 & 400 & 1150 & 4 & none & - & 9.70 & 0.52 & 0.25 & 0.56 & 0.43 & 10.29 \\
\hline P2-9Ca-0F & 9.27 & 0.00 & $\cdots$ & 400 & 1150 & 4 & none & -- & 5.99 & $\cdots$ & -. & -- & -- & - \\
\hline P2-9Ca-1F & 9.18 & 0.91 & 0.90 & 400 & 1150 & 4 & none & - & 5.10 & 0.45 & 0.20 & 0.64 & 0.54 & 10.80 \\
\hline $\mathrm{P} 2-9 \mathrm{Ca}-5 \mathrm{~F}$ & 8.83 & 4.76 & - & 300 & 1150 & $2 \mathrm{~s}$ & none & -. & - & -- & .. & - & -- & - \\
\hline P2-9Ca-6F & 8.70 & 6.10 & -- & 300 & 1100 & $2 \mathrm{~s}$ & ?CaF2? & -. & - & - & 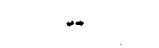 & - & - & $\cdots$ \\
\hline P2-9Ca-8F & 8.58 & 7.41 & - & 300 & $1100 / 1150$ & $1 / 1 \mathrm{~s}$ & $\mathrm{CaF} 2$ & $\ldots$ & - & - & .. &.- & $\because$ & - \\
\hline P2-OCa-OF & 0.00 & 0.00 & - & 20 & 1150 & 4 & none & $\cdots$ & - & 0.30 & 0.27 & 0.04 & 0.69 & 9.17 \\
\hline P2-OCa-IF & 0.00 & 0.91 & 0.72 & 20 & 1150 & 4 & none & none &.- & 0.44 & 0.26 & 0.54 & 0.41 & 10.12 \\
\hline P2-OCa-2F & 0.00 & 1.81 & 0.77 & 20 & 1150 & 4 & none & none & - & 0.49 & 0.25 & 0.56 & 0.41 & 10.08 \\
\hline P2-OCa-3F & 0.00 & 2.72 & 1.24 & 20 & 1150 & 4 & none & none & - & 0.51 & 0.24 & 0.56 & 0.40 & 10.04 \\
\hline P2-0Ca-4F & 0.00 & 3.64 & 1.71 & 20 & 1150 & 4 & none & s. $x u l$ & - & 0.57 & 0.23 & 0.60 & 0.43 & 9.95 \\
\hline P2-0Ca-5P & 0.00 & 4.55 & 1.64 & 20 & 1150 & 4 & none & - & $\ldots$ & 0.58 & 0.23 & 0.61 & 0.44 & 9.83 \\
\hline P2-3Ca-OF & 3.00 & 0.00 & $\overline{--}$ & 20 & 1150 & 4 & none & $\therefore$ & $\ldots$ & 0.22 & 0.16 & 0.06 & 0.55 & 9.42 \\
\hline P2-3Ca-1F & 2.69 & 0.91 & 0.59 & 20 & 1150 & 4 & none & none &.- & 0.44 & 0.22 & 0.58 & 0.44 & 10.40 \\
\hline P2-3Ca-2F & 2.67 & 1.82 & 0.84 & 20 & 1150 & 4 & none & none &.- & 0.46 & 0.23 & 0.57 & 0.40 & 10.30 \\
\hline $\mathrm{P} 2-3 \mathrm{C} z-3 \mathrm{~F}$ & 2.65 & 2.73 & 1.57 & 20 & 1150 & 4 & none & none & - & 0.45 & 0.22 & 0.54 & 0.39 & 10.08 \\
\hline P2-3Ca-4F & 2.62 & 3.65 & 1.52 & 20 & 1150 & 4 & none & s. xtl & - & 0.48 & 0.22 & 0.54 & 0.39 & 10.10 \\
\hline P2-3Ca-SF & 2.60 & 4.56 & 2.59 & 20 & 1150 & 4 & none & .. &.- & 0.54 & 0.22 & 0.56 & 0.40 & 10.07 \\
\hline $\mathrm{P2}-9 \mathrm{Ca}-0 \mathrm{~F}$ & 10.00 & 0.00 & -. & 20 & 1150 & 4 & none & $\ldots$ & - & 0.21 & 0.10 & 0.24 & 0.42 & 10.01 \\
\hline P2-9Ca-1F & 9.18 & 0.91 & 0.61 & 20 & 1150 & 4 & none & none & -- & 0.45 & 0.21 & 0.76 & 0.65 & 10.90 \\
\hline P2-9Ca-2F & 9.10 & 1.83 & 1.08 & 20 & 1150 & 4 & none & none & - & 0.52 & 0.21 & 0.72 & 0.58 & 10.81 \\
\hline P2-9Ca-3F & 9.01 & 2.75 & 1.70 & 20 & 1150 & 4 & none & none & - & 0.57 & 0.24 & 0.81 & 0.65 & 10.83 \\
\hline P2-9C12-4F & 8.93 & 3.67 & 2.34 & 20 & 1150 & 4 & none & s. xtl &.- & 0.60 & 0.23 & 0.78 & 0.64 & 10.80 \\
\hline P2-9Ca-5F & 8.84 & 4.59 & 2.67 & 20 & 1150 & 4 & none & $\therefore$ & $\ldots$ & 0.56 & 0.20 & 0.74 & 0.58 & 10.71 \\
\hline
\end{tabular}




\section{DEFINITIONS}

- $\mathrm{CaO}$-- mass\% in glass on an oxide (target, not measured)

- $\mathrm{F}$ target and $\mathrm{F}$ meas -- mass \% in glass (as measured by ISE)

- Size -- melt size $(20 \mathrm{~g}, 300 \mathrm{~g}$, or $400 \mathrm{~g})$

- $s$-- melt stirred

- Q -- melt quenched (air quenched)

- HT -- heat treated at $650^{\circ} \mathrm{C}$ for 24 hours

- Viscosity -- $1150^{\circ} \mathrm{C}$ (Pa-sec)

- PCT -- 7-day PCT at $90^{\circ} \mathrm{C}$ (in duplicate)

- release normalize to "target" composition

- average $\mathrm{pH}$ of duplicates

\section{SUMMARY}

- Bounds for Phase $2 b$ test matrix defined as:

- $\mathrm{CaO}: 0.0-12.0$ mass $\%$

$-F: 0.0-6.0$ mass $\%$

- $\mathrm{CaO}$ and $\mathrm{F}$ to be varied independently in the Phase $2 b$ test matrix

- Property coefficients obtained from Phase 2a scoping studies were used to define/limit Phase $2 b$ compositional space 


\section{Appendix C \\ Review of CVS Phase 1 Data and Preliminary CVS Phase 2 Models}




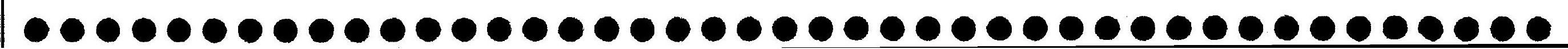




\title{
INEEL CVS Phase 1 Data and Preliminary Models
}

$\star 18$ homogeneous compositions $\star$ PCT anomalies

$\star$ Preliminary first-order mixture models for In PCT boron ( $g / L)$ and $\operatorname{In} \eta_{1150}(\mathrm{~Pa}-\mathrm{s})$

\author{
Greg Piepel \\ Statistics Group \\ Pacific Northwest National Laboratory
}

March 30, 1999 
Data Used for First-Order Mixture Models Out of 18 Homogeneous Glasses

\begin{tabular}{|c|c|c|c|c|c|}
\hline \multirow{2}{*}{ Glass } & \multirow{2}{*}{ Homogeneous? } & \multirow{2}{*}{$\begin{array}{l}16 \text { values, Visc. } \\
\text { at } 1150(\mathrm{~Pa}-\mathrm{s})\end{array}$} & \multicolumn{3}{|c|}{ I7 Values $P C T(g / L)$} \\
\hline & & & $\mathbf{B}$ & Li & $\mathrm{Na}$ \\
\hline IGI-0I & $\mathbf{n}$ & $\star$ & $*$ & & \\
\hline IG1-02 & $\mathbf{n}$ & $\star$ & * & & \\
\hline IG1-03 & $n$ & $\star$ & $\star$ & & \\
\hline IG1-04 & $\mathbf{n}$ & $\star$ & * & & \\
\hline IG1-05 & $\mathbf{n}$ & * & * & & \\
\hline IGI-06 & $y$ & 7.14 & 19.24 & 19.07 & 17.88 \\
\hline IG1-07 & $y$ & 9.44 & 0.56 & 0.72 & 0.12 \\
\hline IGI-08 & $n$ & * & * & & \\
\hline IG1-09 & $\mathbf{n}$ & * & * & & \\
\hline IGI-10 & $\mathbf{Y}$ & 2.91 & 29.35 & 21.31 & 19.02 \\
\hline IGI-II & $y$ & 11.84 & 0.58 & 0.76 & 1.87 \\
\hline IG1-12 & $y$ & 6.51 & 9.21 & ---- & 8.01 \\
\hline IGI-13 & $y$ & not meas. & 59.39 & 46.48 & 58.70 \\
\hline$I G 1-14$ & $y$ & 7.66 & 0.99 & 0.57 & 1.30 \\
\hline IGI-15 & $\mathbf{n}$ & $\star$ & $\star$ & & \\
\hline IGI-16 & $Y$ & 7.83 & 0.70 & 0.43 & 1.19 \\
\hline IG1-17 & $\mathbf{n}$ & * & $\star$ & & \\
\hline IGI-I8 & n & $\star$ & * & & \\
\hline IGI-I9 & $n$ & $\star$ & $*$ & & \\
\hline$I G I-20$ & $n$ & * & $*$ & & \\
\hline$I G I-21$ & $n$ & * & $\star$ & & \\
\hline$I G I-22$ & $n$ & $\star$ & * & & \\
\hline IG1-23 & I & * & $\star$ & & \\
\hline IGI-24 & I & $\star$ & * & & \\
\hline IG1-25 & $\mathbf{n}$ & * & * & & \\
\hline$I G 1-26$ & n & * & $\star$ & & \\
\hline$I G I-27$ & $n$ & * & $\star$ & & \\
\hline IG1-28 & $z$ & * & * & & \\
\hline IGI-29 & $y$ & 15.53 & 0.45 & 0.71 & 0.35 \\
\hline$I G 1-30$ & $y$ & 2.12 & 24.28 & 16.31 & 17.95 \\
\hline IGI-3I & $Y$ & 1.97 & 3.03 & 2.54 & 1.57 \\
\hline$I G I-32$ & I & * & * & & \\
\hline IGI-33 & $y$ & not mesa.? & 11.65 & 19.35 & 21.26 \\
\hline$I G I-34$ & $\mathrm{n}$ & $\star$ & $\star$ & & \\
\hline IGI-35 & $y$ & 9.17 & 0.88 & $36.80 *$ & 0.71 \\
\hline IGI-36 & $y$ & 3.35 & 17.72 & 17.97 & 17.87 \\
\hline IG1-37 & $y$ & 5.88 & $(15,60)^{(a)}$ & 0.10 & 12.74 \\
\hline$I \in 1-38$ & $y$ & 7.33 & 2.45 & 2.22 & 1.48 \\
\hline ICI-39 & $y$ & 2.84 & 3.39 & 2.79 & 2.16 \\
\hline$I G I-40$ & $\mathrm{n}$ & $\star$ & $*$ & & \\
\hline IGI-4I & $\mathbf{n}$ & $\star$ & $\star$ & & \\
\hline$I G 1-42$ & $n$ & * & * & & \\
\hline IG1-43 & $y$ & 7.60 & 1.45 & 0.71 & 1.10 \\
\hline IGI-44 & $\mathbf{n}$ & $\star$ & $*$ & & \\
\hline
\end{tabular}

(a) Outlier in regression diagnostics, not used in model fit 

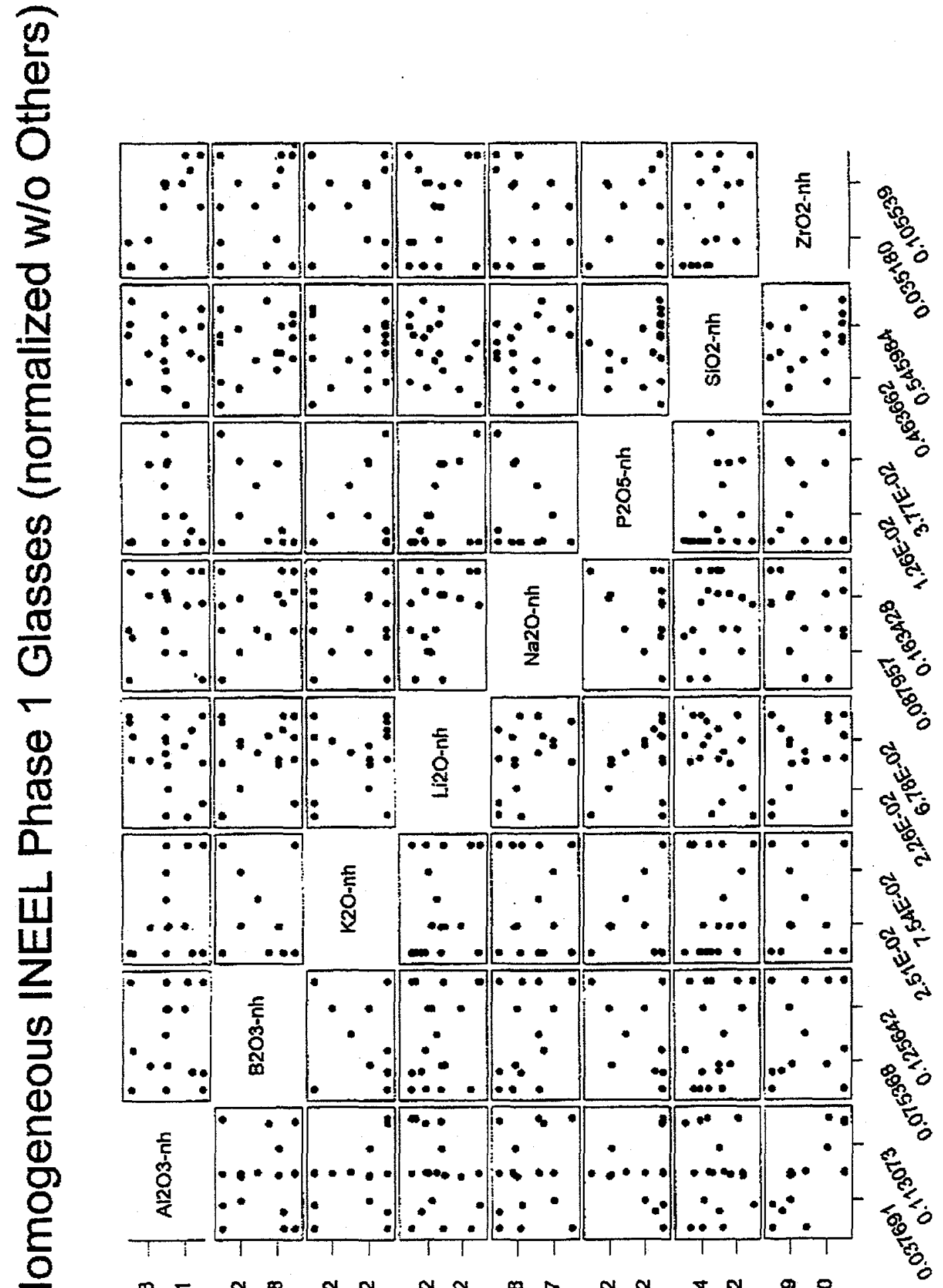

$\frac{1}{10}$

닌

응

$\Phi$

(1)

8

틍

I

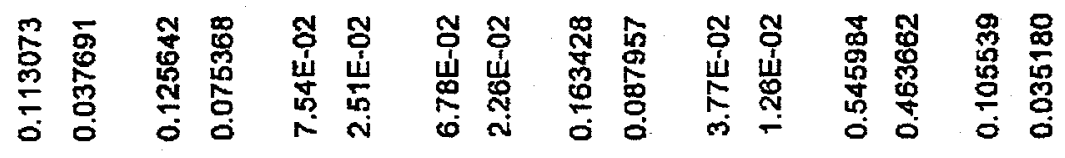




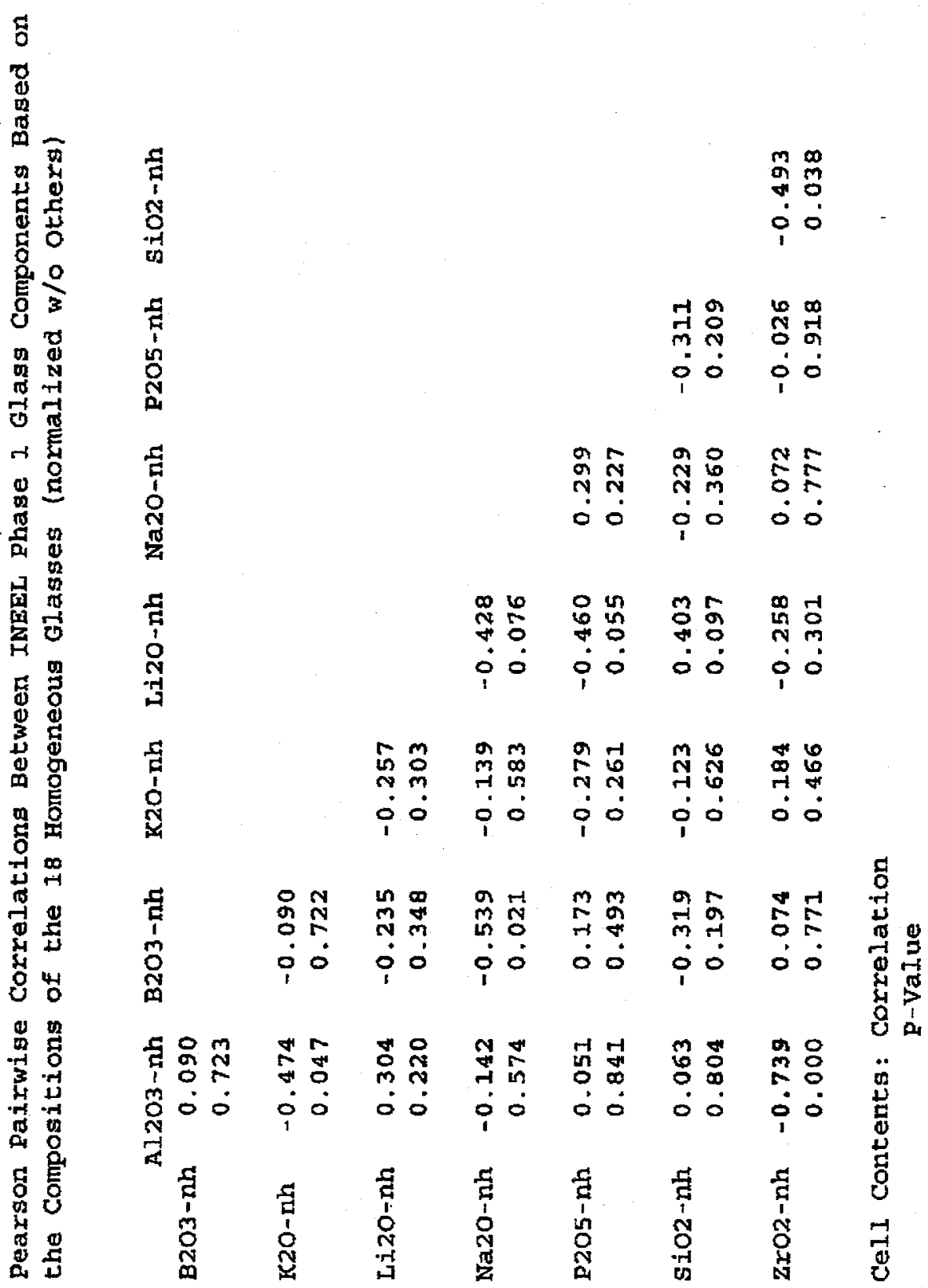


In(PCT, g/L) B, Li, and Na Releases for 18 Homogeneous Glasses

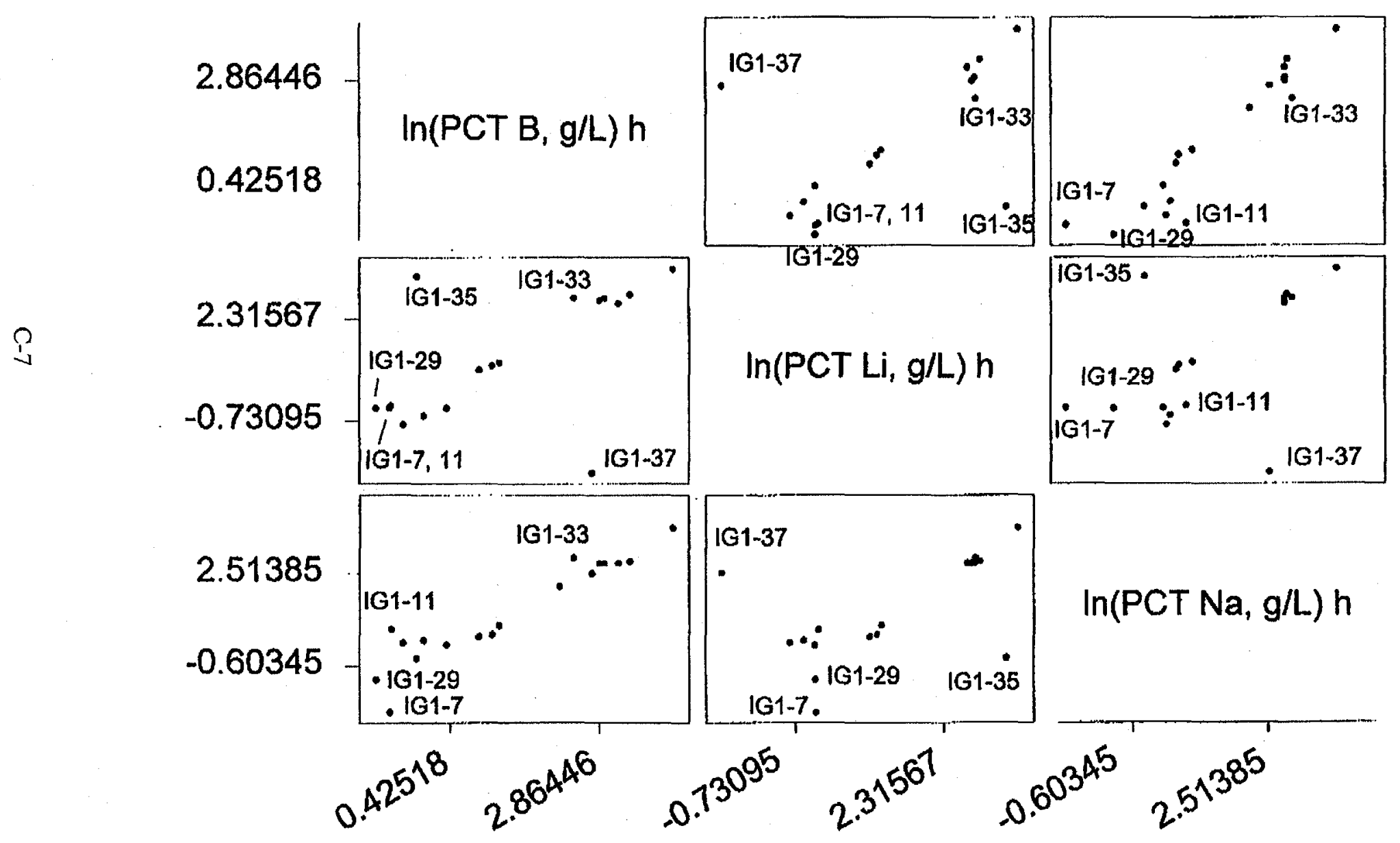




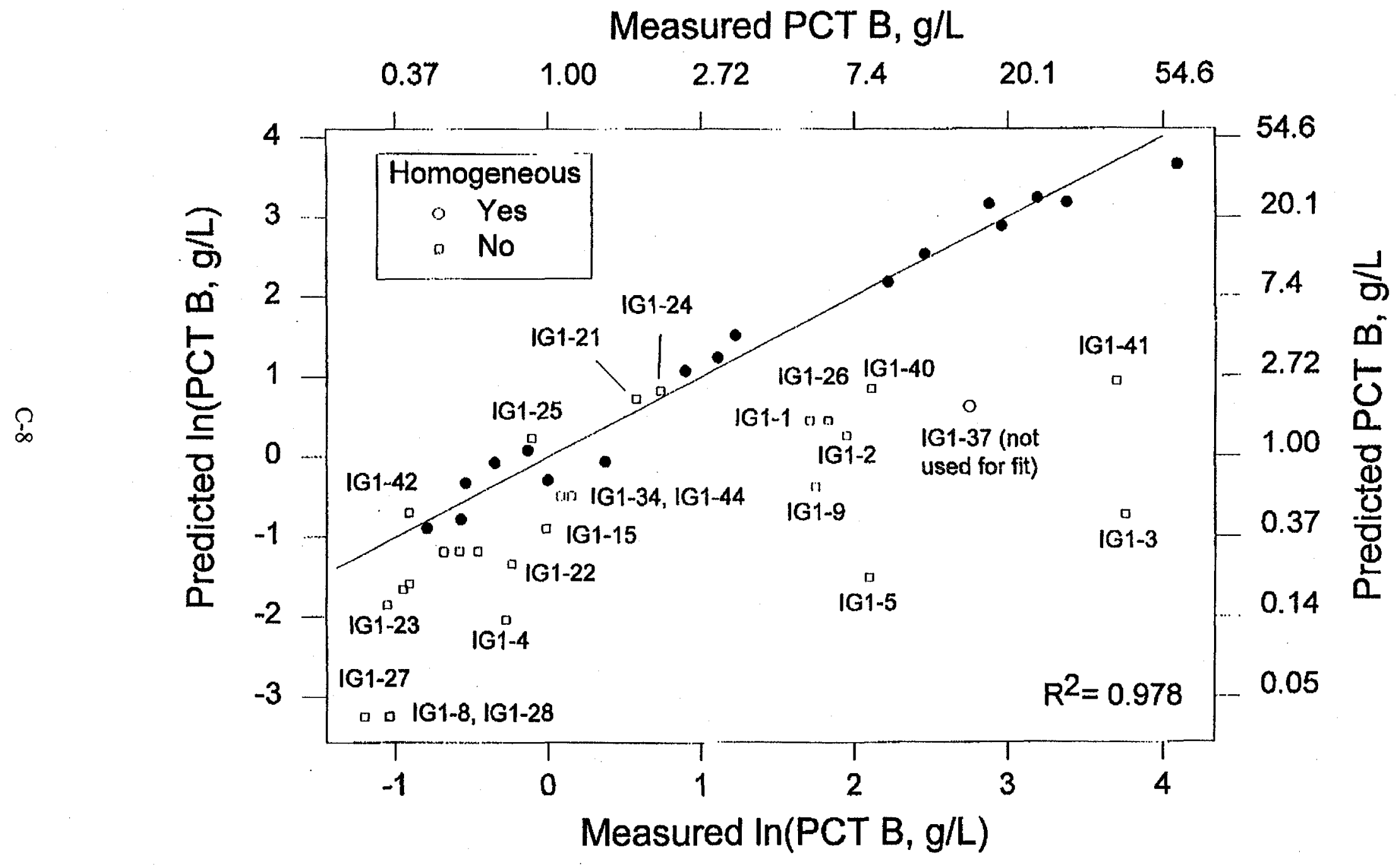




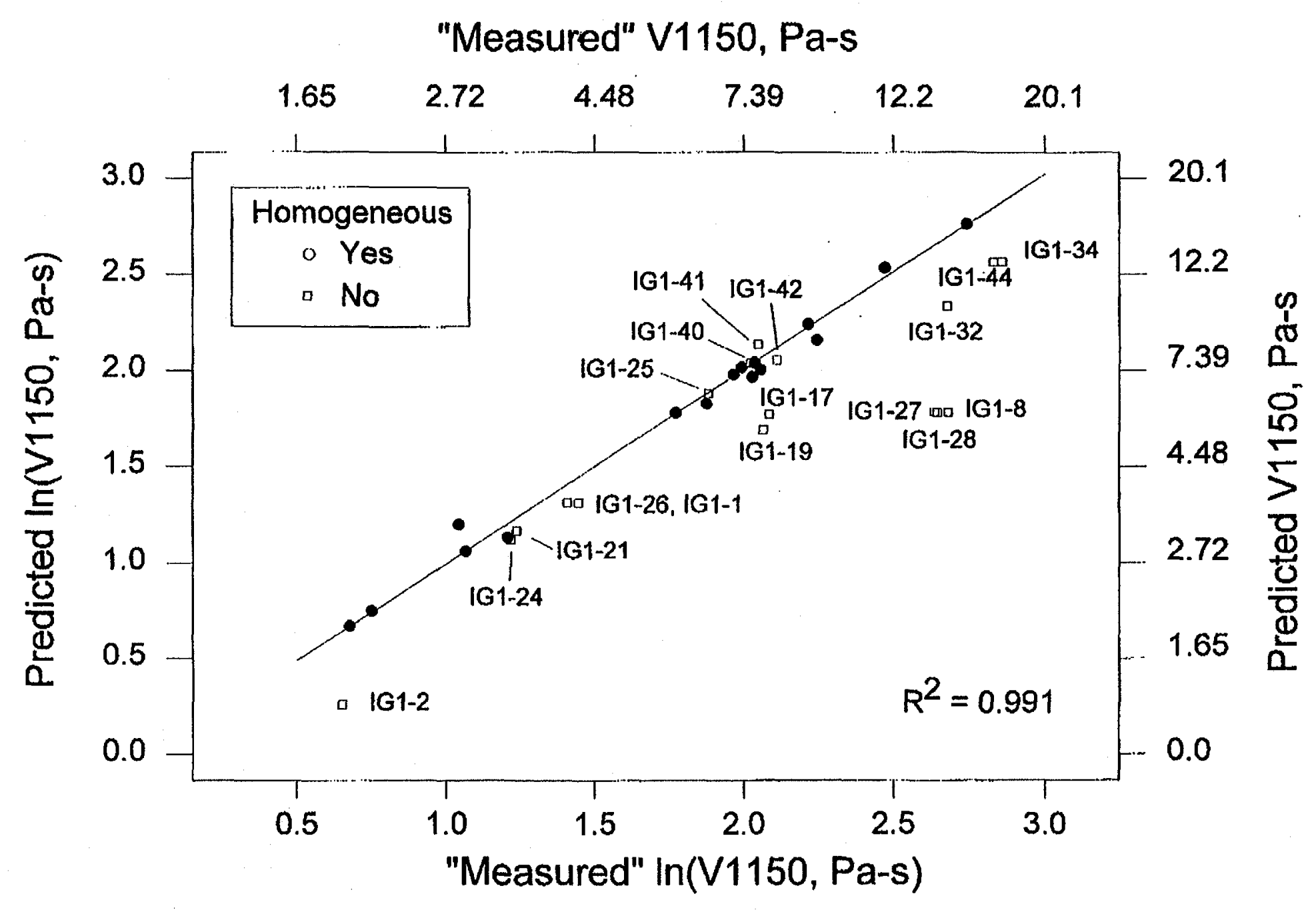




\section{Appendix D \\ Review of Phase 2b CVS Test Matrix}


$\mid \bullet \bullet \bullet \bullet \bullet \bullet \bullet \bullet \bullet \bullet \bullet \bullet \bullet \bullet \bullet \bullet \bullet \bullet \bullet \bullet \bullet \bullet \bullet \bullet \bullet \bullet \bullet \bullet \bullet \bullet \bullet \bullet \bullet \bullet \bullet \bullet \bullet \bullet \bullet \bullet \bullet \bullet \bullet$ 


\section{Presentation and Discussion of Phase $2 b$ CVS Test Matrix}

SRTC

Tommy Edwards

David Peeler
PNNL

Greg Piepel

John Vienna

March 1999 Glass Formulation and Vitrification Development Workshop

March 30-31, 1999 


\section{Components and Their Ranges}

\begin{tabular}{|c|c|c|c|}
\hline & & $\begin{array}{l}\text { Inner } \\
\text { Layer }\end{array}$ & $\begin{array}{l}\text { Outer } \\
\text { Layer }\end{array}$ \\
\hline \multicolumn{2}{|l|}{ Oxide } & Bounds & Bounds \\
\hline \multirow[t]{2}{*}{$\mathrm{Al}_{2} \mathrm{O}_{3}$} & $\min$ & 0.08 & 0.035 \\
\hline & $\max$ & 0.12 & 0.20 \\
\hline \multirow[t]{2}{*}{$\mathrm{B}_{2} \mathrm{O}_{3}$} & $\min$ & 0.06 & 0.05 \\
\hline & $\max$ & 0.12 & 0.18 \\
\hline \multirow[t]{2}{*}{$\mathrm{CaO}$} & $\min$ & 0.04 & 0 \\
\hline & $\max$ & 0.08 & 0.12 \\
\hline \multirow[t]{2}{*}{$\mathbf{F}$} & $\min$ & 0.01 & 0 \\
\hline & $\max$ & 0.025 & 0.06 \\
\hline \multirow[t]{2}{*}{$\mathrm{Fe}_{2} \mathrm{O}_{3}$} & $\min$ & 0.005 & 0 \\
\hline & $\max$ & 0.03 & 0.08 \\
\hline \multirow[t]{2}{*}{$\mathrm{K}_{2} \mathrm{O}$} & $\min$ & 0.03 & 0 \\
\hline & $\max$ & 0.06 & 0.10 \\
\hline \multirow[t]{2}{*}{ Li2O } & $\min$ & 0.03 & 0 \\
\hline & $\max$ & 0.06 & 0.09 \\
\hline \multirow{2}{*}{$\mathrm{Na}_{2} \mathrm{O}$} & $\min$ & 0.10 & 0.05 \\
\hline & $\max$ & 0.15 & 0.20 \\
\hline \multirow[t]{2}{*}{$\mathrm{NiO}$} & $\min$ & 0.005 & 0 \\
\hline & $\max$ & 0.01 & 0.015 \\
\hline \multirow[t]{2}{*}{$\mathrm{P}_{2} \mathrm{O}_{5}$} & $\min$ & 0.01 & 0 \\
\hline & $\max$ & 0.02 & 0.03 \\
\hline \multirow[t]{2}{*}{$\mathrm{SiO} 2$} & $\min$ & 0.40 & 0.35 \\
\hline & $\max$ & 0.50 & 0.60 \\
\hline \multirow[t]{2}{*}{$\mathrm{ZrO}_{2}$} & $\min$ & 0.04 & 0 \\
\hline & $\max$ & 0.08 & 0.14 \\
\hline
\end{tabular}




\section{Estimated Effects for Property Models And Property Bounds}

\begin{tabular}{|c|c|c|c|c|c|}
\hline $\begin{array}{c}\text { Oxide } \\
\mathrm{Al}_{2} \mathrm{O}_{3} \\
\mathrm{~B}_{2} \mathrm{O}_{3} \\
\mathrm{CaO} \\
\mathrm{F} \\
\mathrm{Fe}_{2} \mathrm{O}_{3} \\
\mathrm{~K}_{2} \mathrm{O} \\
\mathrm{Li}_{2} \mathrm{O} \\
\mathrm{Na}_{2} \mathrm{O} \\
\mathrm{NiO} \mathrm{O} \\
\mathrm{P}_{2} \mathrm{O}_{5} \\
\mathrm{SiO}_{2}\end{array}$ & $\begin{array}{c}\text { Electrical } \\
\text { Conductivity } \\
\text { Hanford CVS } \\
\text { ln(Shm) } \\
\text { increases } \\
\text { increases } \\
\text { increases } \\
\text {--(b) } \\
\text { increases } \\
\text { increases (a) } \\
\text { increases } \\
\text { increases } \\
\text {--(b) } \\
\text { - (b) } \\
\text { increases } \\
\text { a - See Phase 1 document } \\
\text { b - No assumption was ma } \\
\text { c - From SPSG Studies } \\
\text { d - From Phase } 2 \text { data } \\
\text { e - From Hanford CVS }\end{array}$ & $\begin{array}{l}\text { Nepheline (a) } \\
\text { decreases } \\
\text { decreases } \\
\text { decreases } \\
\text { increases } \\
\text { de for this effect }\end{array}$ & $\begin{array}{c}\text { Spinel TL (c) } \\
{ }^{\circ} \mathrm{C} \\
\text { increases } \\
\text { increases } \\
\text { increases } \\
- \text {-(b) } \\
\text { increases } \\
\text { decreases } \\
\text { decreases } \\
\text { decreases } \\
\text { increases } \\
\text { increases }\end{array}$ & $\begin{array}{l}\text { In(Visce 1150,Pais) } \\
\text { from INEel Phase } 1 \\
\text { increases } \\
\text { decreases } \\
\text { decreases (d) } \\
\text { decreases (d) } \\
\text { decreases (e) } \\
\text { decreases } \\
\text { decreases } \\
\text { decreases } \\
\text {-(b) } \\
\text { increases } \\
\text { increases }\end{array}$ & $\begin{array}{l}\text { 7-Day PCT NL[B] } \\
\text { In(g/L) } \\
\text { from INEEL Fhase } 1 \\
\text { decreases } \\
\text { increases } \\
\text { decreases (e) } \\
\text {-(b) } \\
\text { decreases (e) } \\
\text { increases } \\
\text { increases } \\
\text { increases } \\
\text {-are(b) } \\
\text { decreases } \\
\text { decreases }\end{array}$ \\
\hline
\end{tabular}

\section{Property Bounds}

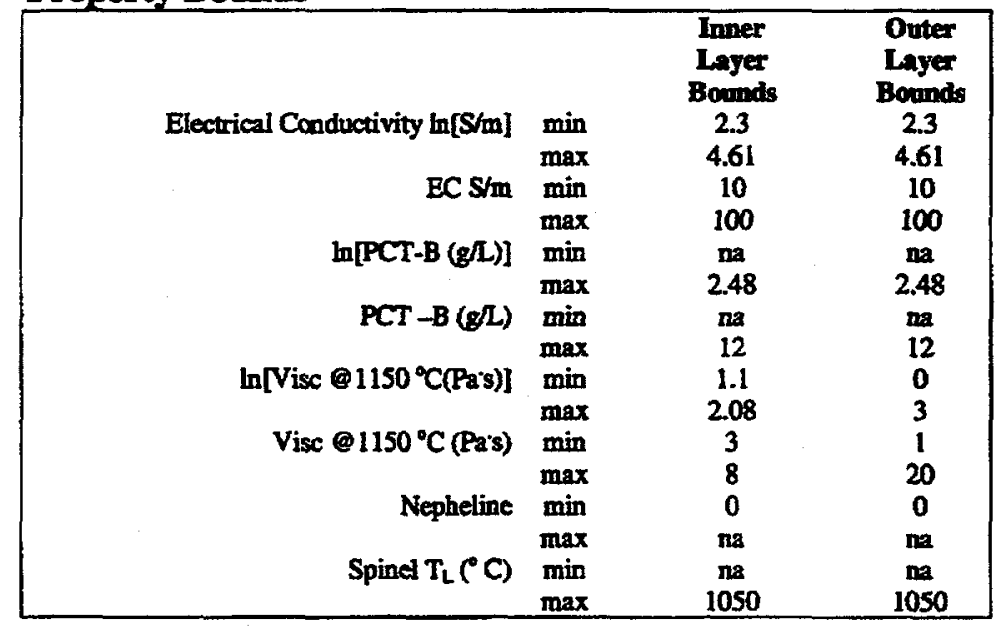




\section{A Couple of Additional Constraints}

\begin{tabular}{|cccc|}
\hline & $\begin{array}{c}\text { Inner } \\
\text { Layer } \\
\text { Bounds }\end{array}$ & $\begin{array}{c}\text { Outer } \\
\text { Layer } \\
\text { Bounds }\end{array}$ \\
$\mathrm{Al}_{2} \mathrm{O}_{3}+\mathrm{ZrO}_{2}$ & $\begin{array}{l}\min \\
\text { Sux }\end{array}$ & 0.22 & 0.22 \\
& & \\
Sum of alkalis & $\begin{array}{c}\min \\
\max \end{array}$ & 0.25 & 0.25 \\
\hline
\end{tabular}




\section{Final EGCR}

Inner and Outer Layers

\begin{tabular}{|c|c|c|c|c|c|c|c|}
\hline 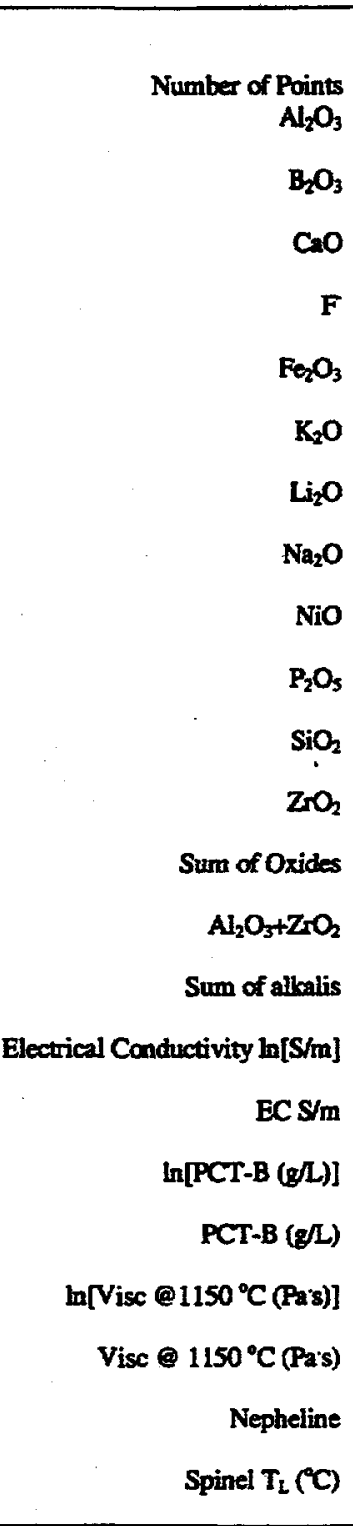 & 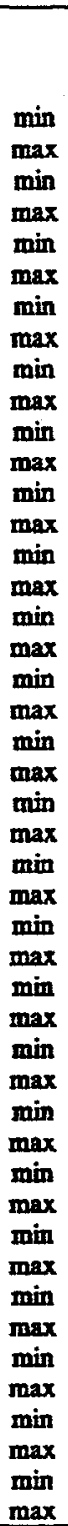 & 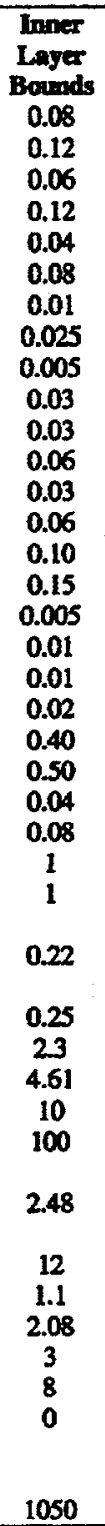 & $\begin{array}{c}\text { Immer } \\
\text { Layer EV's } \\
5663 \\
0.0800 \\
0.1200 \\
0.0600 \\
0.1200 \\
0.0400 \\
0.0800 \\
0.0100 \\
0.0250 \\
0.0050 \\
0.0300 \\
0.0300 \\
0.0600 \\
0.0300 \\
0.0600 \\
0.1000 \\
0.1500 \\
0.0050 \\
0.0100 \\
0.0100 \\
0.0200 \\
0.4000 \\
0.5000 \\
0.0400 \\
0.0800 \\
1.0000 \\
1.0000 \\
0.1200 \\
0.2000 \\
0.1600 \\
0.2500 \\
2.74 \\
3.99 \\
15.5 \\
54.1 \\
-3.43 \\
1.03 \\
0.03 \\
2.8 \\
1.10 \\
2.08 \\
3 \\
1158.2 \\
\end{array}$ & $\begin{array}{c}\text { Imner Layer } \\
\text { Centroid } \\
1 \\
0.1007 \\
0.1007 \\
0.0790 \\
0.0790 \\
0.0558 \\
0.0558 \\
0.0163 \\
0.0163 \\
0.0163 \\
0.0163 \\
0.0439 \\
0.0439 \\
0.0398 \\
0.0398 \\
0.1199 \\
0.1199 \\
0.0074 \\
0.0074 \\
0.0149 \\
0.0149 \\
0.4468 \\
0.4468 \\
0.0592 \\
0.0592 \\
1.0000 \\
1.0000 \\
0.1599 \\
0.1599 \\
0.2035 \\
0.2035 \\
3.25 \\
3.25 \\
25.8 \\
25.8 \\
-1.02 \\
-1.02 \\
0.36 \\
0.36 \\
1.44 \\
1.44 \\
4.2 \\
4.2 \\
0.03 \\
886.4 \\
0.03 \\
0\end{array}$ & $\begin{array}{c}\text { Outer } \\
\text { Layer EV's } \\
10781 \\
0.0350 \\
0.2000 \\
0.0500 \\
0.1800 \\
0.0000 \\
0.1200 \\
0.0000 \\
0.0600 \\
0.0000 \\
0.0800 \\
0.0000 \\
0.1000 \\
0.0000 \\
0.0900 \\
0.0500 \\
0.2000 \\
0.0000 \\
0.0150 \\
0.0000 \\
0.0300 \\
0.3500 \\
0.6000 \\
0.0000 \\
0.1400 \\
1.0000 \\
1.0000 \\
0.0350 \\
0.2200 \\
0.0500 \\
0.2500 \\
1.43 \\
4.91 \\
40.37 \\
1659.0 \\
135.6 \\
-8.54 \\
2.48 \\
0.0002 \\
12 \\
0.00 \\
3.00 \\
1 \\
0.47 \\
\end{array}$ & $\begin{array}{c}\text { Outer Layer } \\
\text { Ceatroid } \\
1 \\
0.0967 \\
0.0967 \\
0.1040 \\
0.1040 \\
0.0420 \\
0.0420 \\
0.0254 \\
0.0254 \\
0.0348 \\
0.0348 \\
0.0441 \\
0.0441 \\
0.0385 \\
0.0385 \\
0.1109 \\
0.1109 \\
0.0073 \\
0.0073 \\
0.0138 \\
0.0138 \\
0.4260 \\
0.4260 \\
0.0565 \\
0.0565 \\
1.0000 \\
1.0000 \\
0.1532 \\
0.1532 \\
0.1935 \\
0.1935 \\
3.17 \\
3.17 \\
23.8 \\
22.8 \\
-0.50 \\
-0.50 \\
0.95 \\
0.95 \\
1.05 \\
1.05 \\
2.9 \\
2.9 \\
0.03 \\
0.03 \\
895.9 \\
895.9 \\
\end{array}$ & 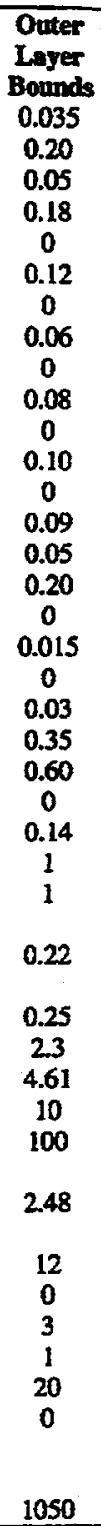 \\
\hline
\end{tabular}


Phase 2b Test Matrix: Compositions as Mass Fractions

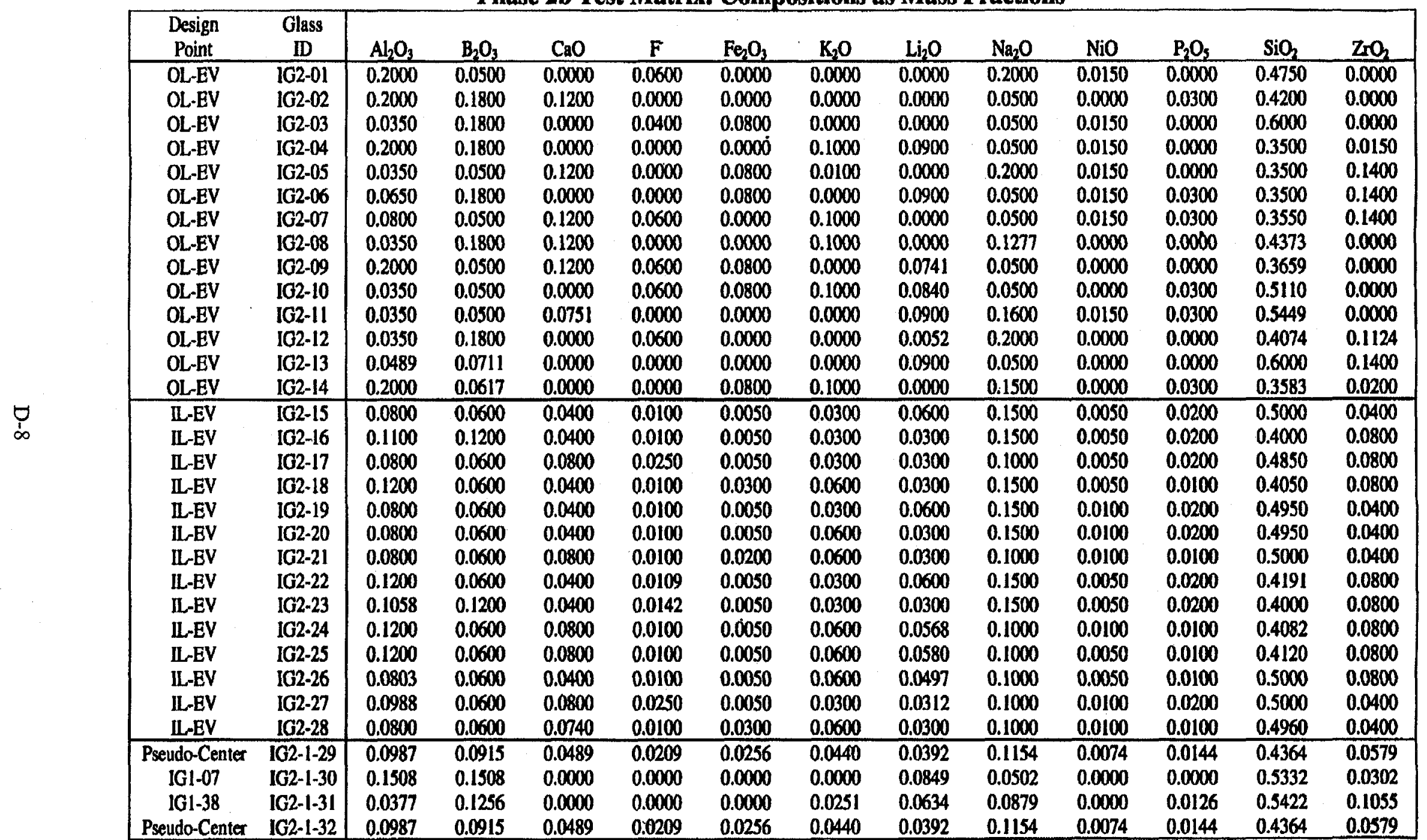

Pseudo-center determined by averaging the Inner-Layer Centroid and Outer-Layer Centroid compositions. 
Phase 2b Test Matrix: Property Predictions

\begin{tabular}{|c|c|c|c|c|c|c|c|c|c|c|c|c|}
\hline $\begin{array}{c}\text { Design } \\
\text { Point } \\
\end{array}$ & $\begin{array}{c}\text { Glass } \\
\text { ID }\end{array}$ & $\begin{array}{l}\text { Sum of } \\
\text { Oxides }\end{array}$ & $\mathrm{Al}_{2} \mathrm{O}_{3}+\mathrm{ZrO}_{2}$ & $\begin{array}{l}\text { Sum of } \\
\text { alkali's }\end{array}$ & \multicolumn{2}{|c|}{$\begin{array}{c}\text { Electrical } \\
\text { Conductivity }\end{array}$} & \multicolumn{2}{|c|}{ PCT-Boron } & \multicolumn{2}{|c|}{ Visc. @1 $150^{\circ} \mathrm{C}$} & Nepheline & $\begin{array}{l}\text { Spinel } T_{L} \\
\left({ }^{\circ} \mathrm{C}\right)\end{array}$ \\
\hline OL-EV & IG2-01 & 1.000 & 0.200 & 0.200 & 2.99 & 19.9 & -3.53 & 0.03 & 2.81 & 16.6 & -0.17 & 870.8 \\
\hline OL-EV & IG2-02 & 1.000 & 0.200 & 0.050 & 1.74 & 5.7 & -6.10 & 0.00 & 2.74 & 15.5 & -0.01 & 1196.4 \\
\hline OL-EV & $1 G 2-03$ & 1.000 & 0.035 & 0.050 & 1.72 & 5.6 & -0.74 & 0.48 & 2.94 & 18.9 & 0.47 & 1044.3 \\
\hline OL-EV & $1 G 2-04$ & 1.000 & 0.215 & 0.240 & 3.90 & 49.4 & 1.27 & 3.56 & 0.07 & 1.1 & -0.22 & 891.9 \\
\hline OL-EV & IG2-05 & 1.000 & 0.175 & 0.210 & 3.22 & 25.0 & -0.94 & 0.39 & 1.00 & 2.7 & -0.01 & 1176.6 \\
\hline OL-EV & 1G2-06 & 1.000 & 0.205 & 0.140 & 3.82 & 45.6 & 1.01 & 2.75 & 0.01 & 1.0 & 0.16 & 1247.8 \\
\hline OL-EV & IG2-07 & 1.000 & 0.220 & 0.150 & 1.65 & 5.2 & -4.37 & 0.01 & 1.45 & 4.3 & 0.00 & 1271.0 \\
\hline OL-EV & IG2-08 & 1.000 & 0.035 & 0.228 & 2.65 & 14.2 & 2.48 & 11.94 & 0.04 & 1.0 & 0.05 & 505.7 \\
\hline OL-EV & IG2-09 & 1.000 & 0.200 & 0.124 & 3.36 & 28.8 & -4.26 & 0.01 & 0.00 & 1.0 & -0.06 & 1205.1 \\
\hline OL-EV & IG2-10 & 1.000 & 0.035 & 0.234 & 3.58 & 35.9 & 1.94 & 6.96 & 0.00 & 1.0 & 0.23 & 549.4 \\
\hline OL-EV & IG2-11 & 1.000 & 0.035 & 0.250 & 4.61 & 100.5 & 2.16 & 8.67 & 0.00 & 1.0 & 0.25 & 542.5 \\
\hline OL-EV & IG2-12 & 1.000 & 0.147 & 0.205 & 3.25 & 25.8 & 2.48 & 11.94 & 0.00 & 1.0 & 0.06 & 617.4 \\
\hline OL-EV & IG2-13 & 1.000 & 0.189 & 0.140 & 3.56 & 35.2 & -0.56 & 0.57 & 3.00 & 20.1 & 0.44 & 1047.3 \\
\hline OL-EV & 1G2-14 & 1.000 & 0.220 & 0.250 & 2.84 & 17.1 & -3.39 & 0.03 & 3.00 & 20.1 & -0.36 & 891.0 \\
\hline IL-EY & IG2-15 & 1.000 & 0.120 & 0.240 & 3.92 & 50.4 & 0.45 & 1.57 & 1.18 & 3.3 & 0.10 & 656.0 \\
\hline IL-EV & $1 G 2-16$ & 1.000 & 0.190 & 0.210 & 3.35 & 28.5 & -0.60 & 0.55 & 1.22 & 3.4 & -0.06 & 847.6 \\
\hline IL-EV & IG2-17 & 1.000 & 0.160 & 0.160 & 2.75 & 15.6 & -2.52 & 0.08 & 2.05 & 7.8 & 0.16 & 979.7 \\
\hline IL-EV & IG2-18 & 1.000 & 0.200 & 0.240 & 3.37 & 29.1 & -1.18 & 0.31 & 1.74 & 5.7 & -0.11 & 896.6 \\
\hline IL-EV & 1G2-19 & 1.000 & 0.120 & 0.240 & 3.92 & 50.4 & 0.48 & 1.62 & 1.14 & 3.1 & 0.09 & 699.3 \\
\hline IL-EV & IG2-20 & 1.000 & 0.120 & 0.240 & 3.29 & 26.8 & -0.26 & 0.77 & 1.91 & 6.8 & 0.05 & 711.7 \\
\hline IL-EV & $1 G 2-21$ & 1.000 & 0.120 & 0.190 & 2.83 & 16.9 & -1.43 & 0.24 & 2.06 & 7.8 & 0.13 & 915.0 \\
\hline IL-EV & IG2-22 & 1.000 & 0.200 & 0.240 & 3.95 & 51.9 & -0.71 & 0.49 & 1.10 & 3.0 & -0.05 & 830.9 \\
\hline IL-EV & $1 G 2-23$ & 1.000 & 0.186 & 0.210 & 3.34 & 28.2 & -0.49 & 0.61 & 1.10 & 3.0 & -0.05 & 835.5 \\
\hline IL-EV & IG2-24 & 1.000 & 0.200 & 0.217 & 3.44 & 31.2 & -1.40 & 0.25 & 1,10 & 3.0 & -0.04 & 1002.0 \\
\hline IL-EV & IG2-25 & 1.000 & 0.200 & 0.218 & 3.48 & 32.5 & -1.37 & 0.25 & 1.10 & 3.0 & -0.03 & 956.0 \\
\hline L-EV & IG2-26 & 1.000 & 0.160 & 0.210 & 3.25 & 25.8 & -0.69 & 0.50 & 2.08 & 8.0 & 0.13 & 868.6 \\
\hline IL.EV & 1G2-27 & 1.000 & 0.139 & 0.161 & 2.77 & 16.0 & -2.62 & 0.07 & 2.08 & 8.0 & 0.14 & 956.0 \\
\hline IL.EV & 1G2-28 & 1.000 & 0.120 & 0.190 & 2.85 & 17.3 & -1.39 & 0.25 & 2.08 & 8.0 & 0.12 & 927.2 \\
\hline Pseudo-Center & IG2-29 & 1.000 & 0.157 & 0.199 & 3.21 & 24.8 & -0.76 & 0.47 & 1.24 & 3.5 & 0.03 & 891.3 \\
\hline IG1-07 & IG2-30 & 1.000 & 0.181 & 0.135 & 3.58 & 35.9 & -0.78 & 0.46 & 2.16 & 8.7 & 0.19 & 930.6 \\
\hline IG1-38 & IG2-31 & 1.000 & 0.143 & 0.176 & 3.44 & 31.2 & 1.08 & 2.94 & 2.02 & 7.5 & 0.31 & 804.9 \\
\hline
\end{tabular}




\section{Scatter Plot Matrix for Phase 2 Design Points}

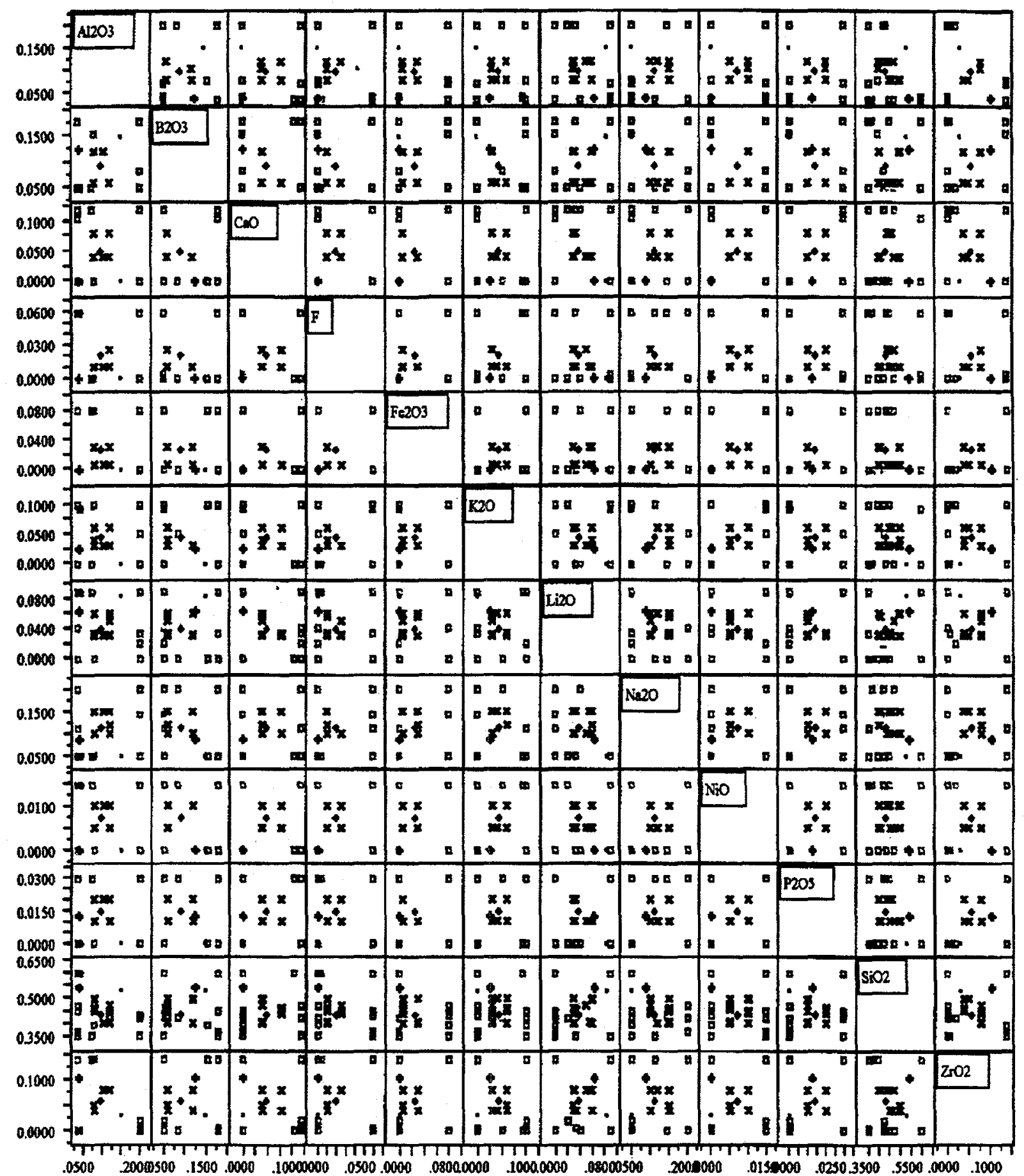


Phase 2b Test Matrix: Target Compositions for Batching



* The IG1-07 and IG1-38 glasses should be batched with "Others" as defined in the Phase 1 study. 


\section{Definition of Others for Phase 2}

\begin{tabular}{|cc|}
\hline Oxide & Weight \% \\
$\mathrm{BaO}$ & 0.61 \\
$\mathrm{CeO}_{2}$ & 0.75 \\
$\mathrm{Cl}^{-}$ & 4.05 \\
$\mathrm{Cr}_{2} \mathrm{O}_{3}$ & 9.12 \\
$\mathrm{Cs}_{2} \mathrm{O}$ & 0.52 \\
$\mathrm{I}$ & 0.31 \\
$\mathrm{La}_{2} \mathrm{O}_{3}$ & 0.35 \\
$\mathrm{MgO}$ & 30.09 \\
$\mathrm{MnO}$ & 1.64 \\
$\mathrm{MoO}$ & 0.94 \\
$\mathrm{NbO}_{3}$ & 2.40 \\
$\mathrm{Nd}_{2} \mathrm{O}_{3}$ & 1.17 \\
$\mathrm{PdO}$ & 0.21 \\
$\mathrm{PrO}_{2}$ & 0.34 \\
$\mathrm{Rb}_{2} \mathrm{O}$ & 0.32 \\
$\mathrm{Rh}_{2} \mathrm{O}_{3}$ & 0.34 \\
$\mathrm{RuO}_{2}$ & 0.57 \\
$\mathrm{Sm}_{2} \mathrm{O}_{3}$ & 0.39 \\
$\mathrm{SnO}_{3}$ & 6.53 \\
$\mathrm{SO}_{3}$ & 30.80 \\
$\mathrm{SrO}_{\mathrm{TcO}}$ & 7.71 \\
$\mathrm{TeO}_{3}$ & 0.33 \\
$\mathrm{Y}_{2} \mathrm{O}_{3}$ & 0.31 \\
$\mathrm{Total}$ & 0.22 \\
& 100.02 \\
\hline
\end{tabular}




\section{Appendix E \\ Review of Full Separations Flowsheet and Compositions}


0
0
0
0
0
0
0
0
0
0
0
0
0
0
0
0
0
0
0
0
0
0
0
0
0
0
0
0 
SBW Material Balance

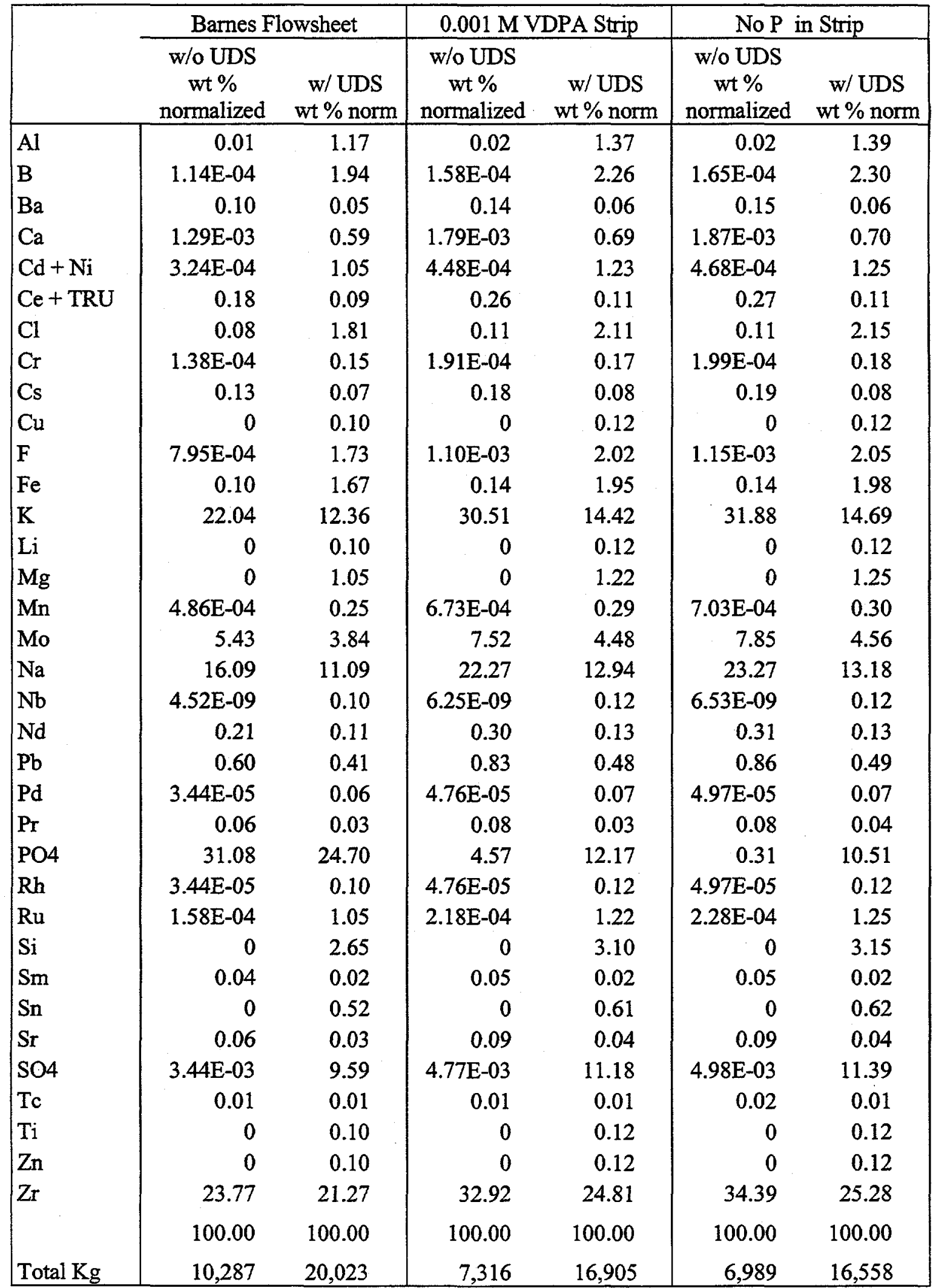




\begin{tabular}{|c|c|c|c|c|c|c|c|c|c|c|c|c|c|c|}
\hline & \multirow[b]{2}{*}{$\begin{array}{l}\text { Weight \% } \\
\text { W/o UDS }\end{array}$} & \multirow[b]{2}{*}{$\begin{array}{l}\text { Weight \% } \\
\text { With UDS } \\
\end{array}$} & \multicolumn{2}{|c|}{$0.001 \mathrm{M}$ VDPA strip } & \multicolumn{2}{|c|}{ No P in strip } & \multicolumn{2}{|c|}{$\begin{array}{c}0.001 \text { M VDPA strip, } \\
\text { Remove } 90 \% \text { of } F \text { from } \\
\text { strip product }\end{array}$} & \multicolumn{2}{|c|}{$\begin{array}{c}0.001 \text { M VDPA strip, } \\
\text { Remove } 99 \% \text { of F from } \\
\text { strip product } \\
\end{array}$} & \multicolumn{2}{|c|}{$\begin{array}{c}\text { No } P \text { in strip, } \\
\text { Remove } 90 \% \text { of } F \text { from } \\
\text { strip product }\end{array}$} & \multicolumn{2}{|c|}{$\begin{array}{c}\text { No } P \text { in strip, } \\
\text { Remove } 99 \% \text { of } F \text { from } \\
\text { strip product }\end{array}$} \\
\hline & & & $\begin{array}{l}\text { Weight } \% \\
\text { W/o UDS }\end{array}$ & $\begin{array}{l}\text { Weight } \% \\
\text { With UDS }\end{array}$ & $\begin{array}{l}\text { Weight } \% \\
\text { W/o UDS }\end{array}$ & $\begin{array}{c}\text { Weight } \% \\
\text { With UDS }\end{array}$ & $\begin{array}{l}\text { Weight \% } \\
\text { W/o UDS }\end{array}$ & $\begin{array}{l}\text { Weight \% } \\
\text { With UDS }\end{array}$ & $\begin{array}{l}\text { Weight \% } \\
\text { W/o UDS }\end{array}$ & $\begin{array}{l}\text { Weight \% } \\
\text { With UDS }\end{array}$ & $\begin{array}{l}\text { Weight \% } \\
\text { W/o UDS }\end{array}$ & $\begin{array}{l}\text { Weight \% } \\
\text { With UDS }\end{array}$ & $\begin{array}{l}\text { Weight \% } \\
\text { W/o UDS }\end{array}$ & $\begin{array}{l}\text { Weight \% } \\
\text { With UDS }\end{array}$ \\
\hline $\mathrm{Al}$ & $4.16 \mathrm{E}-03$ & 3.83 & 0.01 & 5.96 & 0.01 & 6.36 & 0.01 & 7.59 & 0.02 & 7.81 & 0.02 & 8.24 & 0.02 & 8.50 \\
\hline B & $3.84 \mathrm{E}-04$ & 0.35 & $7.89 \mathrm{E}-04$ & 0.55 & 0.00 & 0.59 & $1.32 \mathrm{E}-03$ & 0.70 & $1.42 \mathrm{E}-03$ & 0.72 & $1.65 \mathrm{E}-03$ & 0.76 & $1.80 \mathrm{E}-03$ & 0.78 \\
\hline $\mathrm{Ba}$ & 0.23 & 0.17 & 0.48 & 0.26 & 0.54 & 0.28 & 0.81 & 0.33 & 0.86 & 0.34 & 1.00 & 0.36 & 1.09 & 0.37 \\
\hline $\mathrm{Ca}$ & 0.01 & 11.06 & 0.02 & 17.24 & 0.03 & 18.38 & 0.04 & 21.95 & 0.04 & 22.56 & 0.05 & 23.83 & 0.06 & 24.56 \\
\hline $\mathrm{Ce}+\mathrm{TRU}$ & 0.36 & 0.26 & 0.74 & 0.40 & 0.84 & 0.43 & 1.24 & 0.51 & 1.33 & 0.52 & 1.54 & 0.55 & 1.69 & 0.57 \\
\hline $\mathrm{Cl}$ & $3.68 \mathrm{E}-04$ & 0.04 & $7.56 \mathrm{E}-04$ & 0.06 & $8.56 \mathrm{E}-04$ & 0.07 & $1.27 \mathrm{E}-03$ & 0.08 & $1.36 \mathrm{E}-03$ & 0.08 & $1.58 \mathrm{E}-03$ & 0.08 & $1.73 \mathrm{E}-03$ & 0.09 \\
\hline $\mathrm{Cr}$ & $1.04 \mathrm{E}-04$ & 0.10 & $2.13 \mathrm{E}-04$ & 0.15 & 2.42E-04 & 0.16 & $3.58 \mathrm{E}-04$ & 0.19 & $3.85 \mathrm{E}-04$ & 0.20 & $4.46 \mathrm{E}-04$ & 0.21 & $4.87 \mathrm{E}-04$ & 0.21 \\
\hline $\mathrm{Cs}$ & 0.45 & 0.32 & 0.93 & 0.50 & 1.05 & 0.53 & 1.56 & 0.64 & 1.67 & 0.66 & 1.94 & 0.69 & 2.11 & 0.71 \\
\hline F & 21.89 & 23.09 & 44.96 & 36.00 & 50.93 & 38.38 & 7.58 & 18.52 & 0.84 & 16.23 & 9.44 & 20.11 & 1.07 & 17.66 \\
\hline $\mathrm{Fe}$ & 0.15 & 0.31 & 0.31 & 0.49 & 0.35 & 0.52 & 0.52 & 0.62 & 0.56 & 0.64 & 0.64 & 0.67 & 0.70 & 0.69 \\
\hline $\mathrm{Gd}$ & 0.01 & 0.01 & 0.02 & 0.01 & 0.02 & 0.01 & 0.03 & 0.01 & 0.03 & 0.01 & 0.03 & 0.01 & 0.03 & 0.01 \\
\hline K & 0.76 & 0.70 & 1.56 & 1.09 & 1.77 & 1.17 & 2.63 & 1.39 & 2.82 & 1.43 & 3.27 & 1.51 & 3.57 & 1.56 \\
\hline $\mathrm{Mg}$ & 1.12E-04 & 0.10 & $2.30 \mathrm{E}-04$ & 0.16 & $2.61 \mathrm{E}-04$ & 0.17 & $3.87 \mathrm{E}_{-}-04$ & 0.20 & 4.15E--04 & 0.21 & $4.82 \mathrm{E}-04$ & 0.22 & $5.26 \mathrm{E}-04$ & 0.23 \\
\hline Mo & 7.21 & 5.04 & 14.82 & 7.86 & 16.78 & 8.38 & 24.88 & 10.01 & 26.69 & 10.29 & 30.97 & 10.87 & 33.83 & 11.20 \\
\hline $\mathrm{Na}$ & 2.29 & 2.29 & 4.70 & 3.58 & 5.33 & 3.81 & 7.90 & 4.55 & 8.47 & 4.68 & 9.83 & 4.94 & 10.74 & 5.09 \\
\hline $\mathrm{Nd}$ & 0.57 & 0.40 & 1.16 & 0.63 & 1.32 & 0.67 & 1.95 & 0.80 & 2.09 & 0.82 & 2.43 & 0.87 & 2.65 & 0.90 \\
\hline $\mathrm{Ni}$ & 5.53E-05 & 0.03 & $1.14 \mathrm{E}-04$ & 0.05 & $1.29 \mathrm{E}-04$ & 0.05 & $1.91 \mathrm{E}-04$ & 0.06 & $2.05 \mathrm{E}-04$ & 0.07 & $2.38 \mathrm{E}-04$ & 0.07 & $2.59 \mathrm{E}-04$ & 0.07 \\
\hline $\mathrm{Pb}$ & 0.02 & 0.02 & 0.05 & 0.03 & 0.05 & 0.03 & 0.08 & 0.03 & 0.08 & 0.03 & 0.10 & 0.03 & 0.11 & 0.04 \\
\hline PO4 & 57.61 & 40.28 & 12.91 & 6.89 & 1.36 & 0.72 & 21.68 & 8.77 & 23.26 & 9.02 & 2.50 & 0.94 & 2.73 & 0.97 \\
\hline $\mathrm{Pr}$ & 0.15 & 0.11 & 0.31 & 0.17 & 0.35 & 0.18 & 0.52 & 0.21 & 0.56 & 0.22 & 0.65 & 0.23 & 0.71 & 0.24 \\
\hline $\mathrm{Sm}$ & 0.07 & 0.05 & 0.14 & 0.08 & 0.16 & 0.08 & 0.23 & 0.10 & 0.25 & 0.10 & 0.29 & 0.10 & 0.32 & 0.11 \\
\hline$S n$ & 9.45E-05 & 0.09 & $1.94 \mathrm{E}-04$ & 0.14 & $2.20 \mathrm{E}-04$ & 0.14 & $3.26 \mathrm{E}-04$ & 0.17 & $3.50 \mathrm{E}-04$ & 0.18 & $4.06 \mathrm{E}-04$ & 0.19 & 4.43E-04 & 0.19 \\
\hline $\mathrm{Sr}$ & 8.16 & 5.82 & 16.77 & 9.07 & 18.99 & 9.67 & 28.15 & 11.55 & 30.21 & 11.88 & 35.05 & 12.54 & 38.29 & 12.93 \\
\hline $\mathrm{SO} 4$ & $4.96 \mathrm{E}-05$ & 0.05 & $1.02 \mathrm{E}-04$ & 0.07 & $1.16 \mathrm{E}-04$ & 0.08 & $1.71 \mathrm{E}-04$ & 0.09 & $1.84 \mathrm{E}-04$ & 0.09 & $2.13 \mathrm{E}-04$ & 0.10 & $2.33 \mathrm{E}-04$ & 0.10 \\
\hline $\mathrm{Tc}$ & 0.03 & 0.02 & 0.05 & 0.03 & 0.06 & 0.03 & 0.09 & 0.04 & 0.09 & 0.04 & 0.11 & 0.04 & 0.12 & 0.04 \\
\hline $\mathrm{Zr}$ & 0.03 & 5.48 & 0.06 & 8.54 & 0.07 & 9.11 & 0.10 & 10.88 & 0.11 & 11.18 & 0.13 & 11.81 & 0.14 & 12.17 \\
\hline Total $\mathrm{kg}$ & 25,374 & 35,413 & 11,662 & 21,701 & 10,139 & 20,178 & 7,079 & 17,118 & 6,621 & 16,660 & 5,556 & 15,595 & 5,097 & 15,136 \\
\hline
\end{tabular}


Alumina Calcine

\begin{tabular}{|c|c|c|c|c|c|c|}
\hline & \multirow[b]{2}{*}{$\begin{array}{l}\text { Weight } \% \\
\text { W/o UDS }\end{array}$} & \multirow[b]{2}{*}{$\begin{array}{l}\text { Weight } \% \\
\text { With UDS }\end{array}$} & \multicolumn{2}{|c|}{0.001 M VDPA strip } & \multicolumn{2}{|c|}{ no $P$ in Strip } \\
\hline & & & $\begin{array}{l}\text { Weight \% } \\
\text { W/o UDS }\end{array}$ & $\begin{array}{l}\text { Weight \% } \\
\text { With UDS }\end{array}$ & $\begin{array}{l}\text { Weight } \% \\
\text { W/o UDS }\end{array}$ & $\begin{array}{l}\text { Weight } \% \\
\text { With UDS } \\
\end{array}$ \\
\hline $\mathrm{Al}$ & & 23.43 & & 44.32 & & 49.20 \\
\hline B & & 0.12 & & 0.23 & & 0.26 \\
\hline $\mathrm{Ba}$ & & 0.02 & & 0.03 & & 0.04 \\
\hline $\mathrm{Ce}+\mathrm{TRU}$ & 1.32 & 1.00 & 3.65 & 1.89 & 4.54 & 2.10 \\
\hline $\mathrm{Cl}$ & 0.42 & 0.31 & 1.16 & 0.59 & 1.44 & 0.65 \\
\hline Cs & 1.35 & 1.02 & 3.72 & 1.92 & 4.62 & 2.13 \\
\hline $\mathrm{Eu}$ & 0.03 & 0.02 & 0.09 & 0.05 & 0.11 & 0.05 \\
\hline $\mathrm{Fe}$ & 0.02 & 0.43 & 0.04 & 0.82 & 0.05 & 0.91 \\
\hline Mo & 14.25 & 10.53 & 39.36 & 19.92 & 48.93 & 22.11 \\
\hline $\mathrm{Na}$ & 4.02 & 3.63 & 11.10 & 6.86 & 13.80 & 7.62 \\
\hline $\mathrm{Nd}$ & 2.25 & 1.70 & 6.21 & 3.21 & 7.72 & 3.56 \\
\hline $\operatorname{Pr}$ & 0.62 & 0.47 & 1.72 & 0.89 & 2.14 & 0.99 \\
\hline PO4 & 71.90 & 53.66 & 22.40 & 12.35 & 3.51 & 2.71 \\
\hline $\mathbf{R u}$ & & 0.01 & & 0.03 & & 0.03 \\
\hline $\mathrm{Sm}$ & 0.44 & 0.33 & 1.21 & 0.62 & 1.50 & 0.69 \\
\hline SO4 & & 0.80 & & 1.52 & & 1.69 \\
\hline $\mathrm{Sr}$ & 0.77 & 0.58 & 2.14 & 1.10 & 2.66 & 1.22 \\
\hline Tc & 0.08 & 0.06 & 0.23 & 0.12 & 0.29 & 0.13 \\
\hline $\mathrm{Zr}$ & 2.53 & 1.87 & 6.98 & 3.53 & 8.68 & 3.92 \\
\hline Total kg & 6,101 & 8,087 & 2,133 & 4,118 & 1,692 & 3,677 \\
\hline
\end{tabular}




\section{Appendix F}

Review of Options for Pretreatment/Separations Flowsheet and Their Resulting HAW

Fraction Compositions 
(2) 


\section{Dissolution \& Filtration}

- Large uncertainty in both quantity and composition of UDS

- For calcine dissolution

- UDS assumed to be $2 \%$ of the feed calcine

- UDS composition assumed equal to calcine

- Dissolver effluent filtered, filter normally backwashed to dissover, periodically backwashed to HAW

\section{Cs Sorbant: $\left(\mathrm{NH}_{4}\right)_{3} \mathrm{PO}_{4} \cdot 12 \mathrm{MoO}_{3} \cdot \mathrm{H}_{2} \mathrm{O}$ dissolved in $\mathrm{NaOH}$}

Spent sorbant, wt \% as oxide $\mathrm{MoO}_{3}$

73

$\mathrm{P}_{2} \mathrm{O}_{5}$

3

$\mathrm{Na}_{2} \mathrm{O}$

21

$\mathrm{Cs}_{2} \mathrm{O}$

3 


\section{TRUEX}

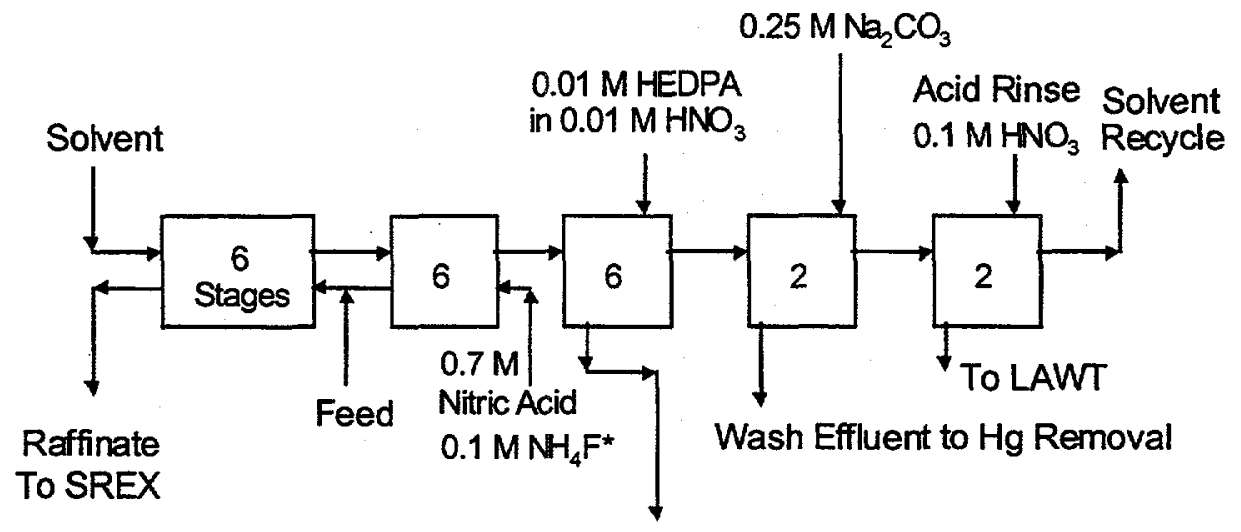

Strip Effluent to HAW Evaporator

Extraction Scrub Strip Wash Rinse

"For Al calcine and SBW, scrub is $0.1 \mathrm{M} \mathrm{HNNO}_{3}$

\section{SREX}

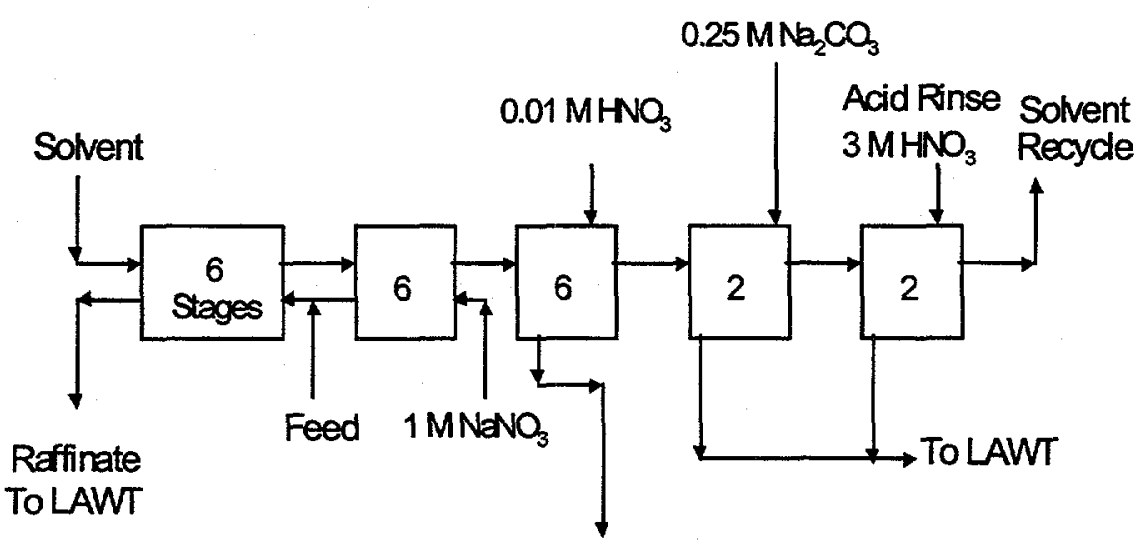

Strip Effluent to HAW Evaporator

Extraction Scrub Strip Wash Rinse 
Total Calcine Feed Case (Bin Sets 1-6)

\begin{tabular}{|c|c|c|c|c|c|c|}
\hline & $\begin{array}{c}\text { Percent } \\
\text { From UDS }\end{array}$ & $\begin{array}{c}\text { Percent from } \\
\text { dissolved } \\
\text { calcine } \\
\end{array}$ & $\begin{array}{c}\text { Percent } \\
\text { from Cs IX } \\
\text { sorbant } \\
\text { dissolution } \\
\end{array}$ & 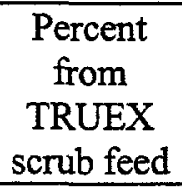 & $\begin{array}{c}\text { Percent } \\
\text { from TRUEX } \\
\text { strip feed }\end{array}$ & $\begin{array}{c}\text { Percent } \\
\text { from SREX } \\
\text { scrub feed }\end{array}$ \\
\hline $\mathrm{Ag}+$ & 99.92 & 0.08 & & & & \\
\hline $\mathrm{Al}+3$ & 99.92 & 0.08 & & & & \\
\hline As+3 & 100.00 & $1.58 \mathrm{E}-06$ & & & & \\
\hline$B+3$ & 99.92 & 0.08 & & & & \\
\hline $\mathrm{Ba}+2$ & 2.63 & 97.37 & . & & & \\
\hline $\mathrm{Ca}+2$ & 99.92 & 0.08 & & & & \\
\hline $\mathrm{Cd}+2$ & 99.92 & 0.08 & & & & \\
\hline $\mathrm{Cl}-$ & 74.57 & 25.43 & & & & \\
\hline $\mathrm{Cr}+3$ & 99.92 & 0.08 & & & & \\
\hline Cst & 2.00 & 0.08 & 98.00 & & & \\
\hline F- & 28.49 & 0.00 & & 71.51 & & \\
\hline $\mathrm{Fe}+3$ & 66.41 & 33.59 & & & & \\
\hline $\mathrm{Gd}+3$ & 2.00 & 98.00 & & & & \\
\hline $\mathrm{Hg}+3$ & 47.53 & 52.47 & & & & \\
\hline $\mathrm{K}+$ & 24.13 & 75.87 & & & & \\
\hline $\mathrm{Mg}+2$ & 99.92 & 0.08 & & & & \\
\hline $\mathrm{Mn}+2$ & 100.00 & 0.00 & & & & \\
\hline $\mathrm{Mo}+6$ & 0.08 & 3.87 & 96.05 & & & \\
\hline $\mathrm{Nat}$ & 12.30 & 0.00 & 25.43 & & & 62.27 \\
\hline $\mathrm{Nb}+5$ & 100.00 & 0.00 & & & & \\
\hline $\mathrm{Ni}+2$ & 99.88 & 0.12 & & & & \\
\hline $\mathrm{Pb}+2$ & 2.00 & 98.00 & & & & \\
\hline PO4-3 & 0.43 & 0.00 & 1.07 & & 98.50 & \\
\hline $\mathrm{Sn}+4$ & 99.92 & 0.08 & & & & \\
\hline $\mathrm{Sr}+2$ & 2.00 & 98.00 & & & & \\
\hline SO4-2 & 99.92 & 0.08 & & & & \\
\hline $\mathrm{Zr}+4$ & 99.61 & 0.39 & & & & \\
\hline Total & 28.77 & 4.05 & 7.46 & 15.23 & 40.30 & 4.20 \\
\hline
\end{tabular}


Zirconia Calcine Feed Case (Bin Set 4)

\begin{tabular}{|c|c|c|c|c|c|c|}
\hline & $\begin{array}{c}\text { Percent } \\
\text { From UDS }\end{array}$ & $\begin{array}{c}\text { Percent from } \\
\text { dissolved } \\
\text { calcine } \\
\end{array}$ & $\begin{array}{c}\text { Percent } \\
\text { from Cs IX } \\
\text { sorbant } \\
\text { dissolution } \\
\end{array}$ & 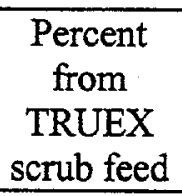 & $\begin{array}{c}\text { Percent } \\
\text { from TRUEX } \\
\text { strip feed }\end{array}$ & $\begin{array}{c}\text { Percent } \\
\text { from SREX } \\
\text { scrub feed } \\
\end{array}$ \\
\hline $\mathrm{Ag}+$ & 100.00 & 0.00 & & & & \\
\hline $\mathrm{Al}+3$ & 99.92 & 0.08 & & & & \\
\hline $\mathrm{As}+3$ & 100.00 & 0.00 & & & & \\
\hline $\mathrm{B}+3$ & 99.92 & 0.08 & & & & \\
\hline $\mathrm{Ba}+2$ & 2.63 & 97.37 & & & & \\
\hline $\mathrm{Ca}+2$ & 99.92 & 0.08 & & & & \\
\hline $\mathrm{Cd}+2$ & 99.92 & 0.08 & & & & \\
\hline $\mathrm{Cl}-$ & 99.35 & 0.65 & & & & \\
\hline $\mathrm{Cr}+3$ & 99.92 & 0.08 & & & & \\
\hline $\mathrm{Cs}+$ & 2.00 & & 98.00 & & & \\
\hline F- & 33.76 & 0.00 & & 66.24 & & \\
\hline $\mathrm{Fe}+3$ & 66.41 & 33.59 & & & & \\
\hline $\mathrm{Gd}+3$ & 2.00 & 98.00 & & & & \\
\hline $\mathrm{Hg}+3$ & 47.53 & 52.47 & & & & \\
\hline $\mathrm{K}+$ & 24.13 & 75.87 & & & & \\
\hline $\mathrm{Mg}+2$ & 99.92 & 0.08 & & & & \\
\hline $\mathrm{Mo}+6$ & 0.04 & 2.01 & 97.95 & & & \\
\hline $\mathrm{Nat}$ & 10.65 & 0.00 & 24.55 & & & 64.80 \\
\hline $\mathrm{Nb}+5$ & 100.00 & 0.00 & & & & \\
\hline $\mathrm{Ni}+2$ & 99.88 & 0.12 & & & & \\
\hline PO4-3 & 0.07 & 0.00 & 1.00 & & 98.93 & \\
\hline $\mathrm{Sn}+4$ & 99.92 & 0.08 & & & & \\
\hline $\mathrm{Sr}+2$ & 2.00 & 98.00 & & & & \\
\hline SO4-2 & 99.92 & 0.08 & & & & \\
\hline $\mathrm{Zr}+4$ & 99.61 & 0.39 & & & & \\
\hline Total & 29.61 & 5.84 & 6.71 & 14.79 & 38.96 & 4.08 \\
\hline
\end{tabular}


Alumina Calcine Feed Case (Bin Set 1)

\begin{tabular}{|l|c|c|c|c|}
\hline & Percent from UDS & $\begin{array}{c}\text { Percent from } \\
\text { dissolved calcine }\end{array}$ & $\begin{array}{c}\text { Percent from } \\
\text { Cs IX sorbant } \\
\text { dissolution }\end{array}$ & $\begin{array}{c}\text { Percent from } \\
\text { TRUEX strip feed }\end{array}$ \\
\hline $\mathrm{Al}$ & 100.00 & & & \\
\hline $\mathrm{B}$ & 100.00 & & & \\
\hline $\mathrm{Cs}$ & 2.00 & & 98.00 & \\
\hline $\mathrm{Fe}$ & 97.40 & 2.60 & & \\
\hline $\mathrm{Hg}$ & 51.20 & 48.80 & & \\
\hline $\mathrm{Mo}$ & 0.26 & 12.68 & 87.06 & \\
\hline $\mathrm{Na}$ & 18.12 & & 81.88 & \\
\hline $\mathrm{PO} 4$ & 1.00 & & & 1.40 \\
\hline $\mathrm{SO} 4$ & 79.03 & 20.97 & & 97.61 \\
\hline $\mathrm{Sr}$ & 2.00 & 98.00 & & \\
\hline $\mathrm{Zr}$ & 2.00 & 98.00 & & \\
\hline Total & 27.46 & 5.16 & 14.12 & \\
\hline
\end{tabular}


Sodium Bearing Waste

\begin{tabular}{|l|c|c|c|c|c|}
\hline & $\begin{array}{c}\text { Percent } \\
\text { From UDS }\end{array}$ & $\begin{array}{c}\text { Percent from } \\
\text { dissolved } \\
\text { calcine }\end{array}$ & $\begin{array}{c}\text { Percent from } \\
\text { dissolved } \\
\text { IX sorbant }\end{array}$ & $\begin{array}{c}\text { Percent } \\
\text { from TRUEX } \\
\text { strip feed }\end{array}$ & $\begin{array}{c}\text { Percent } \\
\text { from SREX } \\
\text { scrub feed }\end{array}$ \\
\hline $\mathrm{Al}$ & 99.48 & 0.52 & & & \\
\hline $\mathrm{B}$ & 100.00 & 0.00 & & & \\
\hline $\mathrm{Ca}$ & 99.89 & 0.11 & & & \\
\hline $\mathrm{Cd}$ & 99.90 & 0.10 & & & \\
\hline $\mathrm{Cl}$ & 97.79 & 2.21 & & & \\
\hline $\mathrm{Cr}$ & 99.95 & 0.05 & & & \\
\hline $\mathrm{Cs}$ & 0.00 & 0.00 & 100.00 & & \\
\hline $\mathrm{Cu}$ & 100.00 & 0.00 & & & \\
\hline $\mathrm{F}$ & 99.98 & 0.02 & & & \\
\hline $\mathrm{Fe}$ & 96.94 & 3.06 & & & \\
\hline $\mathrm{Hg}$ & 76.70 & 23.30 & & & \\
\hline $\mathrm{K}$ & 8.42 & 91.58 & & & \\
\hline $\mathrm{Li}$ & 100.00 & 0.00 & & & \\
\hline $\mathrm{Mg}$ & 100.00 & 0.00 & & & \\
\hline $\mathrm{Mn}$ & 99.90 & 0.10 & & & \\
\hline $\mathrm{Mo}$ & 27.33 & 38.61 & 34.06 & & \\
\hline $\mathrm{Na}$ & 25.49 & 0.00 & 3.82 & & \\
\hline $\mathrm{Nb}$ & 100.00 & 0.00 & & & \\
\hline $\mathrm{Ni}$ & 99.99 & 0.01 & & & \\
\hline $\mathrm{Pb}$ & 25.46 & 74.54 & & & \\
\hline $\mathrm{PO} 4$ & 35.36 & 0.17 & 0.27 & 64.20 & \\
\hline $\mathrm{Se}$ & 0.00 & 100.00 & & & \\
\hline $\mathrm{Si}$ & 100.00 & 0.00 & & & \\
\hline $\mathrm{Sn}$ & 100.00 & 0.00 & & & \\
\hline $\mathrm{SO} 4$ & 99.98 & 0.02 & & & \\
\hline $\mathrm{Sr}$ & 0.00 & 100.00 & & & \\
\hline $\mathrm{Ti}$ & 100.00 & 0.00 & & & \\
\hline $\mathrm{Zn}$ & 100.00 & 0.00 & & & \\
\hline $\mathrm{Zr}$ & 42.58 & 57.42 & & & \\
\hline $\mathrm{Total}$ & 41.04 & 37.55 & 1.56 & & \\
\hline & & & & & \\
\hline
\end{tabular}




\begin{tabular}{|c|c|c|c|c|c|c|}
\hline $\begin{array}{c}\text { Total } \\
\text { Cacline }\end{array}$ & $\begin{array}{r}\text { Low } \\
\mathrm{Kg}\end{array}$ & $\begin{array}{c}\text { Expected } \\
\mathrm{Kg}\end{array}$ & $\begin{array}{l}\text { High } \\
\mathrm{Kg}\end{array}$ & $\begin{array}{l}\text { Low } \\
W \mathfrak{t} \%\end{array}$ & $\begin{array}{c}\text { Expected } \\
\mathrm{W} \mathfrak{t} \%\end{array}$ & $\begin{array}{l}\text { High } \\
\text { Wt\% }\end{array}$ \\
\hline $\mathrm{Al}$ & 19422.7 & 19427.7 & 19510.0 & 6.92 & 6.60 & 6.44 \\
\hline $\mathrm{B}$ & 840.8 & 840.8 & 840.8 & 0.30 & 0.29 & 0.28 \\
\hline $\mathrm{Ba}$ & 143.4 & 495.0 & 504.8 & 0.05 & 0.17 & 0.17 \\
\hline $\mathrm{Ca}$ & 23904.6 & 23910.8 & 24012.1 & 8.52 & 8.12 & 7.92 \\
\hline $\mathrm{Ce}+\mathrm{TRU}$ & 717.3 & 717.3 & 717.3 & 0.26 & 0.24 & 0.24 \\
\hline $\mathrm{Cl}$ & 117.3 & 117.3 & 117.3 & 0.04 & 0.04 & 0.04 \\
\hline $\mathrm{Cr}$ & 185.1 & 185.1 & 185.1 & 0.07 & 0.06 & 0.06 \\
\hline Cs & 825.5 & 825.5 & 825.5 & 0.29 & 0.28 & 0.27 \\
\hline $\mathrm{F}$ & 62282.6 & 62282.6 & 62282.6 & 22.20 & 21.14 & 20.55 \\
\hline $\mathrm{Fe}$ & 467.5 & 686.8 & 1140.2 & 0.17 & 0.23 & 0.38 \\
\hline $\mathrm{K}$ & 1069.6 & 2216.0 & 3208.8 & 0.38 & 0.75 & 1.06 \\
\hline $\mathrm{Mg}$ & 562.0 & 562.0 & 562.0 & 0.20 & 0.19 & 0.19 \\
\hline Mo & 16108.0 & 16160.1 & 16160.1 & 5.74 & 5.49 & 5.33 \\
\hline $\mathrm{Na}$ & 7453.7 & 19753.4 & 8668.7 & 2.66 & 6.71 & 2.86 \\
\hline $\mathrm{Nb}$ & 63.2 & 63.2 & 63.2 & 0.02 & 0.02 & 0.02 \\
\hline $\mathrm{Nd}$ & 1066.1 & 1066.1 & 1066.1 & 0.38 & 0.36 & 0.35 \\
\hline $\mathrm{Ni}+\mathrm{Cd}$ & 1047.9 & 1047.9 & 1047.9 & 0.37 & 0.36 & 0.35 \\
\hline $\mathrm{Pb}$ & 32.5 & 35.3 & 36.0 & 0.01 & 0.01 & 0.01 \\
\hline $\mathrm{PO} 4$ & 117868.5 & 117868.5 & 117868.5 & 42.02 & 40.01 & 38.90 \\
\hline Pr & 290.7 & 290.7 & 290.7 & 0.10 & 0.10 & 0.10 \\
\hline $\mathrm{Sm}$ & 143.0 & 143.0 & 143.0 & 0.05 & 0.05 & 0.05 \\
\hline $\mathrm{Sn}$ & 190.1 & 190.1 & 190.1 & 0.07 & 0.06 & 0.06 \\
\hline $\mathrm{Sr}$ & 12542.2 & 12542.2 & 12542.2 & 4.47 & 4.26 & 4.14 \\
\hline $\mathrm{SO} 4$ & 1099.5 & 1099.5 & 1099.5 & 0.39 & 0.37 & 0.36 \\
\hline $\mathrm{Tc}$ & 41.8 & 41.8 & 41.8 & 0.01 & 0.01 & 0.01 \\
\hline $\mathrm{Zr}$ & 12004.3 & 12004.3 & 29895.1 & 4.28 & 4.08 & 9.87 \\
\hline Total Kg & 280,490 & 294,573 & 303,019 & 100.00 & 100.00 & 100.00 \\
\hline
\end{tabular}




\begin{tabular}{|c|c|c|c|c|c|c|}
\hline $\begin{array}{c}\text { Zirconia } \\
\text { Cacline }\end{array}$ & $\begin{array}{r}\text { Low } \\
\mathrm{Kg}\end{array}$ & $\begin{array}{c}\text { Expected } \\
\mathrm{Kg}\end{array}$ & $\begin{array}{c}\text { High } \\
\mathrm{Kg}\end{array}$ & $\begin{array}{l}\text { Low } \\
W t \%\end{array}$ & $\begin{array}{c}\text { Expected } \\
\mathrm{Wt} \%\end{array}$ & $\begin{array}{l}\text { High } \\
\mathrm{Wt} \%\end{array}$ \\
\hline $\mathrm{Al}$ & 1351.0 & 1351.3 & 1357.0 & 3.85 & 3.67 & 3.52 \\
\hline $\mathrm{B}$ & 124.7 & 124.7 & 124.7 & 0.36 & 0.34 & 0.32 \\
\hline $\mathrm{Ba}$ & 17.1 & 59.2 & 60.4 & 0.05 & 0.16 & 0.16 \\
\hline $\mathrm{Ca}$ & 3905.1 & 3906.1 & 3922.7 & 11.12 & 10.61 & 10.18 \\
\hline $\mathrm{Ce}+\mathrm{TRU}$ & 90.5 & 90.5 & 90.5 & 0.26 & 0.25 & 0.23 \\
\hline $\mathrm{Cl}$ & 13.9 & 13.9 & 13.9 & 0.04 & 0.04 & 0.04 \\
\hline $\mathrm{Cr}$ & 33.8 & 33.8 & 33.8 & 0.10 & 0.09 & 0.09 \\
\hline $\mathrm{Cs}$ & 113.6 & 113.6 & 113.6 & 0.32 & 0.31 & 0.29 \\
\hline $\mathrm{F}$ & 8156.1 & 8156.1 & 8156.1 & 23.23 & 22.15 & 21.16 \\
\hline $\mathrm{Fe}$ & 75.1 & 110.4 & 183.3 & 0.21 & 0.30 & 0.48 \\
\hline $\mathrm{Gd}$ & 1.7 & 1.9 & 1.9 & 0.00 & 0.01 & 0.00 \\
\hline $\mathrm{K}$ & 119.6 & 247.7 & 358.7 & 0.34 & 0.67 & 0.93 \\
\hline $\mathrm{Mg}$ & 36.4 & 36.4 & 36.4 & 0.10 & 0.10 & 0.09 \\
\hline Mo & 1778.2 & 1781.1 & 1781.1 & 5.06 & 4.84 & 4.62 \\
\hline $\mathrm{Na}$ & 810.2 & 2301.8 & 932.8 & 2.31 & 6.25 & 2.42 \\
\hline $\mathrm{Nd}$ & 142.5 & 142.5 & 142.5 & 0.41 & 0.39 & 0.37 \\
\hline $\mathrm{Ni}$ & 11.4 & 11.4 & 11.4 & 0.03 & 0.03 & 0.03 \\
\hline $\mathrm{Pb}$ & 5.2 & 5.7 & 5.8 & 0.01 & 0.02 & 0.02 \\
\hline $\mathrm{PO} 4$ & 14231.0 & 14231.0 & 14231.0 & 40.52 & 38.65 & 36.92 \\
\hline $\mathrm{Pr}$ & 38.2 & 38.2 & 38.2 & 0.11 & 0.10 & 0.10 \\
\hline $\mathrm{Sm}$ & 17.1 & 17.1 & 17.1 & 0.05 & 0.05 & 0.04 \\
\hline $\mathrm{Sn}$ & 30.7 & 30.7 & 30.7 & 0.09 & 0.08 & 0.08 \\
\hline $\mathrm{Sr}$ & 2055.8 & 2055.8 & 2055.8 & 5.85 & 5.58 & 5.33 \\
\hline $\mathrm{SO} 4$ & 16.1 & 16.1 & 16.1 & 0.05 & 0.04 & 0.04 \\
\hline Tc & 6.3 & 6.3 & 6.3 & 0.02 & 0.02 & 0.02 \\
\hline $\mathrm{Zr}$ & 1936.1 & 1936.1 & 4821.6 & 5.51 & 5.26 & 12.51 \\
\hline Total Kg & 35,118 & 36,819 & 38,543 & 100.00 & 100.00 & 100.00 \\
\hline
\end{tabular}




\begin{tabular}{|l|r|r|r|r|r|r|r|}
\hline $\begin{array}{c}\text { Alumina } \\
\text { Cacline }\end{array}$ & $\begin{array}{c}\text { Low } \\
\mathrm{Kg}\end{array}$ & $\begin{array}{c}\text { Expected } \\
\mathrm{Kg}\end{array}$ & $\begin{array}{c}\text { High } \\
\mathrm{Kg}\end{array}$ & & $\begin{array}{c}\text { Low } \\
\text { Wt\% }\end{array}$ & $\begin{array}{c}\text { Expected } \\
\text { Wt\% }\end{array}$ & $\begin{array}{c}\text { High } \\
\text { Wt\% }\end{array}$ \\
\hline $\mathrm{Al}$ & 1895.4 & 1895.4 & 1905.0 & & 23.51 & 23.43 & 23.30 \\
\hline $\mathrm{B}$ & 10.0 & 10.0 & 10.0 & & 0.12 & 0.12 & 0.12 \\
\hline $\mathrm{Ba}$ & 1.5 & 1.5 & 1.5 & & 0.02 & 0.02 & 0.02 \\
\hline $\mathrm{Ce}+\mathrm{TRU}$ & 80.7 & 80.7 & 80.7 & & 1.00 & 1.00 & 0.99 \\
\hline $\mathrm{Cl}$ & 25.1 & 25.1 & 25.1 & & 0.31 & 0.31 & 0.31 \\
\hline $\mathrm{Cs}$ & 82.2 & 82.2 & 82.2 & & 1.02 & 1.02 & 1.01 \\
\hline $\mathrm{Eu}$ & 2.0 & 2.0 & 2.0 & & 0.02 & 0.02 & 0.02 \\
\hline $\mathrm{Fe}$ & 34.8 & 34.9 & 84.9 & & 0.43 & 0.43 & 1.04 \\
\hline $\mathrm{Mo}$ & 840.9 & 851.9 & 851.9 & & 10.43 & 10.53 & 10.42 \\
\hline $\mathrm{Na}$ & 293.4 & 293.4 & 320.0 & & 3.64 & 3.63 & 3.91 \\
\hline $\mathrm{Nd}$ & 137.3 & 137.3 & 137.3 & & 1.70 & 1.70 & 1.68 \\
\hline $\mathrm{Pr}$ & 38.0 & 38.0 & 38.0 & & 0.47 & 0.47 & 0.47 \\
\hline $\mathrm{PO} 4$ & 4341.0 & 4341.0 & 4341.0 & & 53.84 & 53.66 & 53.10 \\
\hline $\mathrm{Ru}$ & 1.1 & 1.1 & 1.1 & & 0.01 & 0.01 & 0.01 \\
\hline $\mathrm{Sm}$ & 26.7 & 26.7 & 26.7 & & 0.33 & 0.33 & 0.33 \\
\hline $\mathrm{SO} 4$ & 64.9 & 64.9 & 64.9 & & 0.81 & 0.80 & 0.79 \\
\hline $\mathrm{Sr}$ & 47.2 & 47.2 & 47.2 & & 0.59 & 0.58 & 0.58 \\
\hline $\mathrm{Tc}$ & 5.0 & 5.0 & 5.0 & & 0.06 & 0.06 & 0.06 \\
\hline $\mathrm{Zr}$ & 136.0 & 151.1 & 151.1 & & 1.69 & 1.87 & 1.85 \\
\hline $\mathrm{Total}$ & 8,063 & 8,089 & 8,176 & & 100.00 & 100.00 & 100.00 \\
\hline
\end{tabular}




\begin{tabular}{|l|r|r|r|r|r|r|r|}
\hline $\begin{array}{c}\text { SBW } \\
\mathrm{HAW}\end{array}$ & $\begin{array}{c}\text { Low } \\
\mathrm{Kg}\end{array}$ & $\begin{array}{c}\text { Expected } \\
\mathrm{Kg}\end{array}$ & $\begin{array}{c}\text { High } \\
\mathrm{Kg}\end{array}$ & & $\begin{array}{c}\text { Low } \\
\mathrm{Kg}\end{array}$ & $\begin{array}{c}\text { Expected } \\
\mathrm{Kg}\end{array}$ & $\begin{array}{c}\text { High } \\
\mathrm{Kg}\end{array}$ \\
\hline $\mathrm{Al}$ & 234.4 & 234.9 & 241.5 & $\mathrm{Nb}$ & 20.1 & 20.1 & 20.1 \\
\hline $\mathrm{B}$ & 388.2 & 388.2 & 388.2 & $\mathrm{Nd}$ & 21.9 & 21.9 & 20.1 \\
\hline $\mathrm{Ba}$ & 7.3 & 10.6 & 14.6 & $\mathrm{~Pb}$ & 51.5 & 82.5 & 83.2 \\
\hline $\mathrm{Ca}$ & 118.4 & 118.4 & 119.1 & $\mathrm{Pd}$ & 12.6 & 12.6 & 12.6 \\
\hline $\mathrm{Cd}+\mathrm{Ni}$ & 211.1 & 211.1 & 211.1 & $\mathrm{Pr}$ & 6.0 & 6.0 & 6.0 \\
\hline $\mathrm{Ce}+\mathrm{TRU}$ & 19.0 & 19.0 & 19.0 & $\mathrm{PO}$ & 4946.6 & 4946.6 & 4946.6 \\
\hline $\mathrm{Cl}$ & 361.8 & 361.8 & 361.8 & $\mathrm{Rh}$ & 21.0 & 21.0 & 21.0 \\
\hline $\mathrm{Cr}$ & 29.9 & 29.9 & 29.9 & $\mathrm{Ru}$ & 210.0 & 210.0 & 210.0 \\
\hline $\mathrm{Cs}$ & 13.5 & 13.5 & 13.5 & $\mathrm{Si}$ & 531.3 & 531.3 & 531.3 \\
\hline $\mathrm{Cu}$ & 21.0 & 21.0 & 21.0 & $\mathrm{Sm}$ & 3.9 & 3.9 & 3.9 \\
\hline $\mathrm{F}$ & 346.1 & 346.1 & 346.1 & $\mathrm{Sn}$ & 105.0 & 105.0 & 105.0 \\
\hline $\mathrm{Fe}$ & 326.7 & 334.2 & 490.3 & $\mathrm{Sr}$ & 6.6 & 6.6 & 6.6 \\
\hline $\mathrm{K}$ & 914.9 & 2475.1 & 3741.3 & $\mathrm{SO}$ & 1919.6 & 1919.6 & 1919.6 \\
\hline $\mathrm{Li}$ & 21.0 & 21.0 & 21.0 & $\mathrm{Tc}$ & 1.1 & 1.1 & 1.1 \\
\hline $\mathrm{Mg}$ & 210.0 & 210.0 & 210.0 & $\mathrm{Ti}$ & 21.0 & 21.0 & 21.0 \\
\hline $\mathrm{Mn}$ & 50.6 & 50.6 & 50.6 & $\mathrm{Zn}$ & 21.0 & 21.0 & 21.0 \\
\hline $\mathrm{Mo}$ & 738.7 & 768.3 & 768.4 & $\mathrm{Zr}$ & 1087.8 & 4258.9 & 6930.8 \\
\hline $\mathrm{Na}$ & 925.5 & 2220.8 & 3397.8 & $\mathrm{Total}$ & 13,925 & 20,023 & 25,307 \\
\hline
\end{tabular}




\begin{tabular}{|l|c|c|c|c|c|c|c|}
\hline $\begin{array}{c}\text { SBW } \\
\mathrm{HAW}\end{array}$ & $\begin{array}{c}\text { Low } \\
\mathrm{Wt} \%\end{array}$ & $\begin{array}{c}\text { Expected } \\
\text { Wt\% }\end{array}$ & $\begin{array}{c}\text { High } \\
\mathrm{Wt} \%\end{array}$ & & $\begin{array}{c}\text { Low } \\
\text { Wt\% }\end{array}$ & $\begin{array}{c}\text { Expected } \\
\text { Wt\% }\end{array}$ & $\begin{array}{c}\text { High } \\
\text { Wt\% }\end{array}$ \\
\hline $\mathrm{Al}$ & 1.68 & 1.17 & 0.95 & $\mathrm{Nb}$ & 0.14 & 0.10 & 0.08 \\
\hline $\mathrm{B}$ & 2.79 & 1.94 & 1.53 & $\mathrm{Nd}$ & 0.16 & 0.11 & 0.09 \\
\hline $\mathrm{Ba}$ & 0.05 & 0.05 & 0.06 & $\mathrm{~Pb}$ & 0.37 & 0.41 & 0.33 \\
\hline $\mathrm{Ca}$ & 0.85 & 0.59 & 0.47 & $\mathrm{Pd}$ & 0.09 & 0.06 & 0.05 \\
\hline $\mathrm{Cd}+\mathrm{Ni}$ & 1.52 & 1.05 & 0.83 & $\mathrm{Pr}$ & 0.04 & 0.03 & 0.02 \\
\hline $\mathrm{Ce}+\mathrm{TRU}$ & 0.14 & 0.09 & 0.08 & $\mathrm{PO} 4$ & 35.52 & 24.70 & 19.55 \\
\hline $\mathrm{Cl}$ & 2.60 & 1.81 & 1.43 & $\mathrm{Rh}$ & 0.15 & 0.10 & 0.08 \\
\hline $\mathrm{Cr}$ & 0.21 & 0.15 & 0.12 & $\mathrm{Ru}$ & 1.51 & 1.05 & 0.83 \\
\hline $\mathrm{Cs}$ & 0.10 & 0.07 & 0.05 & $\mathrm{Si}$ & 3.82 & 2.65 & 2.10 \\
\hline $\mathrm{Cu}$ & 0.15 & 0.10 & 0.08 & $\mathrm{Sm}$ & 0.03 & 0.02 & 0.02 \\
\hline $\mathrm{F}$ & 2.49 & 1.73 & 1.37 & $\mathrm{Sn}$ & 0.75 & 0.52 & 0.41 \\
\hline $\mathrm{Fe}$ & 2.35 & 1.67 & 1.94 & $\mathrm{Sr}$ & 0.05 & 0.03 & 0.03 \\
\hline $\mathrm{K}$ & 6.57 & 12.36 & 14.78 & $\mathrm{SO}$ & 13.79 & 9.59 & 7.59 \\
\hline $\mathrm{Li}$ & 0.15 & 0.10 & 0.08 & $\mathrm{Tc}$ & 0.01 & 0.01 & 0.00 \\
\hline $\mathrm{Mg}$ & 1.51 & 1.05 & 0.83 & $\mathrm{Ti}$ & 0.15 & 0.10 & 0.08 \\
\hline $\mathrm{Mn}$ & 0.36 & 0.25 & 0.20 & $\mathrm{Zn}$ & 0.15 & 0.10 & 0.08 \\
\hline $\mathrm{Mo}$ & 5.31 & 3.84 & 3.04 & $\mathrm{Zr}$ & 7.81 & 21.27 & 27.39 \\
\hline $\mathrm{Na}$ & 6.65 & 11.09 & 13.43 & $\mathrm{Total}$ & 100.00 & 100.00 & 100.00 \\
\hline
\end{tabular}


Estimated INEEL calcine binset compositions in Wt\%

\begin{tabular}{|c|c|c|c|c|c|c|c|}
\hline Element & Binset \#1 & Binset \#2 & Binset \#3 & Binset \#4 & Binset \#5 & Binset \#6 & SBW \\
\hline $\mathrm{Al}$ & 89.56 & 35.17 & 14.56 & 12.69 & 14.84 & 151.65 & 20.20 \\
\hline B & 0.47 & 0.80 & 1.06 & 1.17 & 1.20 & 0.92 & 0.28 \\
\hline $\mathrm{Ba}$ & 0.07 & 0.02 & 0.01 & 0.01 & 0.01 & 0.01 & 0.00 \\
\hline $\mathrm{Ca}$ & 0.00 & 24.45 & 32.83 & 36.67 & 33.19 & 15.84 & 2.22 \\
\hline $\mathrm{Ce}$ & 0.08 & 0.02 & 0.01 & 0.02 & 0.02 & 0.01 & 0.00 \\
\hline $\mathrm{Cl}$ & 0.00 & 0.00 & 0.05 & 0.13 & 0.19 & 0.28 & 1.45 \\
\hline $\mathrm{Cr}$ & 0.00 & 0.20 & 0.27 & 0.32 & 0.17 & 0.27 & 0.24 \\
\hline Cs & 0.06 & 0.02 & 0.01 & 0.02 & 0.01 & 0.01 & 0.00 \\
\hline $\mathrm{F}$ & 0.00 & 21.28 & 26.81 & 25.86 & 21.97 & 7.43 & 1.36 \\
\hline $\mathrm{Fe}$ & 1.58 & 0.17 & 0.30 & 0.69 & 0.70 & 1.31 & 1.51 \\
\hline I & 0.00 & 0.00 & 0.00 & 0.00 & 0.00 & 0.01 & 0.02 \\
\hline $\mathrm{K}$ & 0.00 & 0.18 & 0.25 & 0.56 & 0.90 & 2.60 & 9.17 \\
\hline $\mathrm{La}$ & 0.04 & 0.01 & 0.01 & 0.01 & 0.01 & 0.01 & 0.00 \\
\hline $\mathrm{Mg}$ & 0.00 & 0.71 & 0.83 & 0.34 & 0.62 & 1.12 & 0.05 \\
\hline $\mathrm{Mn}$ & 0.00 & 0.00 & 0.03 & 0.00 & 0.03 & 0.10 & 0.84 \\
\hline Mo & 0.10 & 0.03 & 0.01 & 0.01 & 0.01 & 0.01 & 0.12 \\
\hline $\mathrm{Na}$ & 2.48 & 0.86 & 1.27 & 2.30 & 4.47 & 9.53 & 51.84 \\
\hline $\mathrm{Nb}$ & 0.00 & 0.00 & 0.01 & 0.01 & 0.28 & 0.01 & 0.00 \\
\hline $\mathrm{Nd}$ & 0.13 & 0.04 & 0.02 & 0.03 & 0.03 & 0.02 & 0.00 \\
\hline $\mathrm{Ni}$ & 0.00 & 0.06 & 0.08 & 0.11 & 4.00 & 1.75 & 0.60 \\
\hline $\mathrm{Pb}$ & 0.00 & 0.00 & 0.00 & 0.00 & 0.00 & 0.00 & 0.40 \\
\hline $\mathrm{Pd}$ & 0.01 & 0.00 & 0.00 & 0.00 & 0.00 & 0.00 & 0.00 \\
\hline $\mathrm{PO} 4$ & 2.02 & 0.43 & 1.25 & 0.09 & 0.24 & 0.54 & 2.23 \\
\hline $\operatorname{Pr}$ & 0.04 & 0.01 & 0.01 & 0.01 & 0.01 & 0.01 & 0.00 \\
\hline $\mathrm{Rb}$ & 0.01 & 0.00 & 0.00 & 0.00 & 0.00 & 0.00 & 0.00 \\
\hline $\mathrm{Rh}$ & 0.01 & 0.00 & 0.00 & 0.00 & 0.00 & 0.00 & 0.00 \\
\hline $\mathrm{Ru}$ & 0.05 & 0.01 & 0.00 & 0.00 & 0.01 & 0.01 & 0.05 \\
\hline $\mathrm{Si}$ & 0.00 & 0.00 & 0.00 & 0.00 & 0.00 & 0.00 & 0.12 \\
\hline $\mathrm{Sm}$ & 0.03 & 0.01 & 0.00 & 0.00 & 0.00 & 0.00 & 0.00 \\
\hline $\mathrm{Sn}$ & 0.00 & 0.23 & 0.30 & 0.29 & 0.21 & 0.07 & 0.02 \\
\hline $\mathrm{SO} 4$ & 3.03 & 0.68 & 0.65 & 0.15 & 2.72 & 2.19 & 6.24 \\
\hline $\mathrm{Sr}$ & 0.04 & 0.26 & 0.34 & 0.39 & 0.35 & 0.13 & 0.00 \\
\hline Tc & 0.03 & 0.01 & 0.00 & 0.00 & 0.01 & 0.00 & 0.00 \\
\hline $\mathrm{Te}$ & 0.01 & 0.00 & 0.00 & 0.00 & 0.00 & 0.00 & 0.00 \\
\hline $\mathrm{U}$ & 0.02 & 0.01 & 0.01 & 0.01 & 0.02 & 0.16 & 0.00 \\
\hline$Y$ & 0.00 & 0.00 & 0.01 & 0.01 & 0.01 & 0.00 & 0.00 \\
\hline $\mathrm{Zr}$ & 0.14 & 14.34 & 19.01 & 18.12 & 13.79 & 4.10 & 1.03 \\
\hline Total & 100.00 & 100.00 & 100.00 & 100.00 & 100.00 & 100.00 & 100.00 \\
\hline
\end{tabular}

